\title{
Regional Fluid Flow and Basin Modeling in Northern Alaska
}

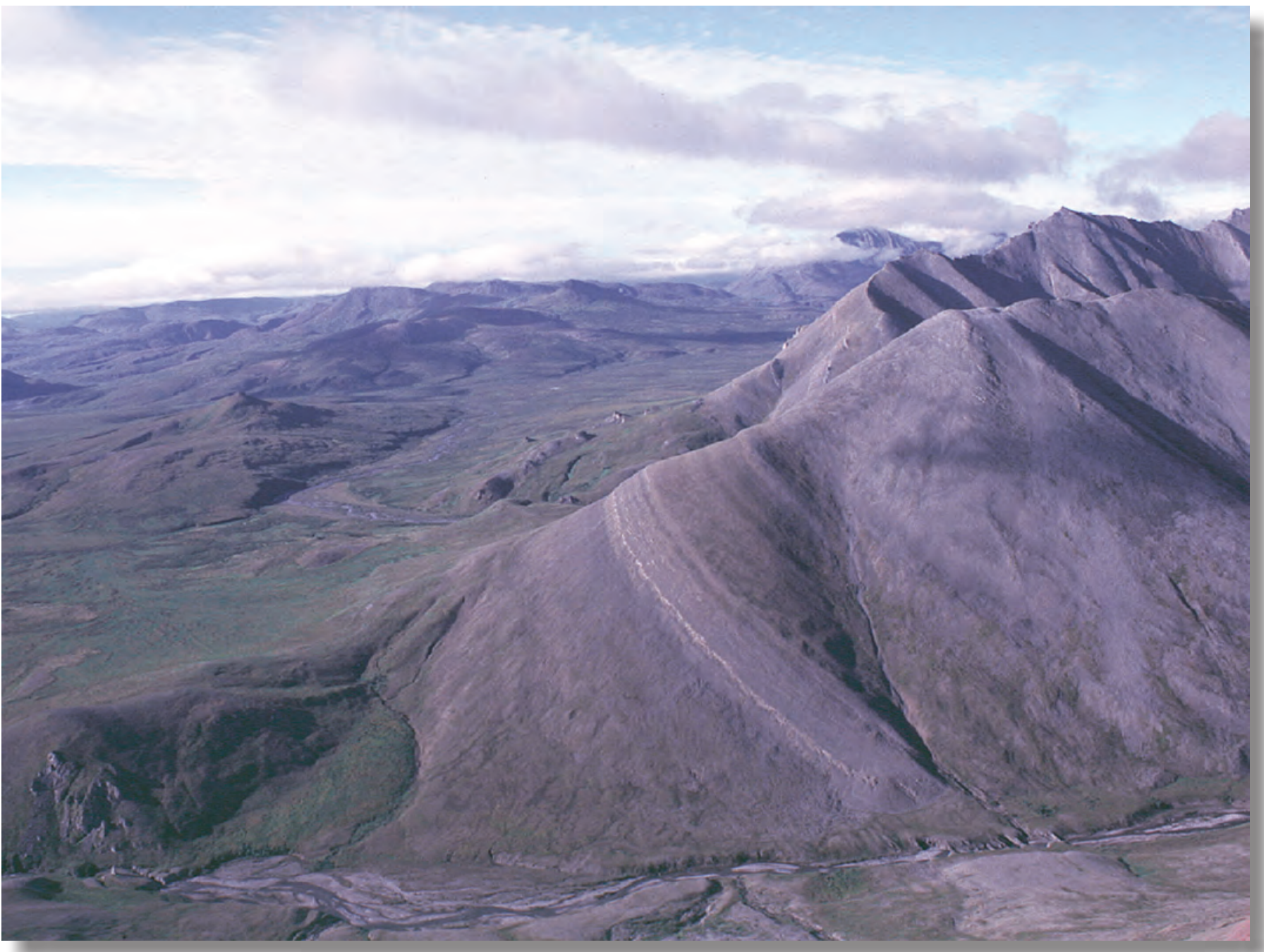

Circular 1319

Contributors

Robert A. Ayuso

Robert C. Burruss

Julie A. Dumoulin

Garth E. Graham

Anita G. Harris
Craig A. Johnson

Karen D. Kelley

David L. Leach

Paul G. Lillis
Erin E. Marsh

Thomas E. Moore

Christopher J. Potter

John F. Slack 


\section{Regional Fluid Flow and Basin Modeling in Northern Alaska}

Contributors: Robert A. Ayuso, Robert C. Burruss, Julie A. Dumoulin, Garth E. Graham, Anita G. Harris, Craig A. Johnson, Karen D. Kelley, David L. Leach, Paul G. Lillis, Erin E. Marsh, Thomas E. Moore, Christopher J. Potter, John F. Slack

Circular 1319 


\section{U.S. Department of the Interior DIRK KEMPTHORNE, Secretary}

\section{U.S. Geological Survey \\ Mark D. Myers, Director}

\section{U.S. Geological Survey, Reston, Virginia: 2008}

For product and ordering information:

World Wide Web: http://www.usgs.gov/pubprod

Telephone: 1-888-ASK-USGS

For more information on the USGS--the Federal source for science about the Earth, its natural and living resources, natural hazards, and the environment:

World Wide Web: http://www.usgs.gov

Telephone: 1-888-ASK-USGS

Any use of trade, product, or firm names is for descriptive purposes only and does not imply endorsement by the U.S. Government.

Although this report is in the public domain, permission must be secured from the individual copyright owners to reproduce any copyrighted materials contained within this report.

Suggested citation:

Kelley, K.D., ed., 2008, Regional fluid flow and basin modeling in northern Alaska: U.S. Geological Survey Circular 1319, $45 \mathrm{p}$. 


\section{Contents}

1. Introduction.

2. Depositional Settings and Age of Carboniferous Rocks in the Western Brooks

Range, Alaska 3

3. Geochemistry of Paleozoic Sedimentary Rocks: Metallogenic Significance ................................6

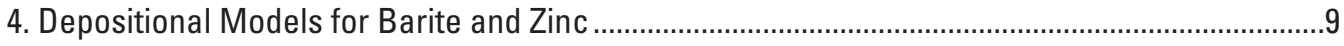

5. Insights into the Ore-Forming Fluids ....................................................................................... 12

6. Geochemical Indicators of Massive Sulfide Deposits and Vein Breccia Zn-Pb-Ag

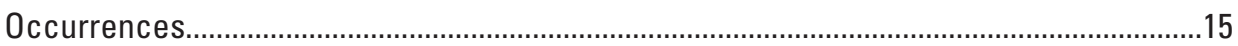

7. Sulfur and Oxygen Isotope Chemistry of Barite ............................................................................18

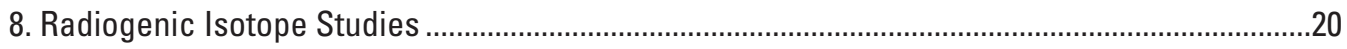

9. Phosphatic Rocks of the Lisburne Group ...................................................................................22

10. Metalliferous Tasmanite and Oil Shale .....................................................................................25

11. Preliminary Retrodeformable Regional Cross Section, Western Brooks Range .......................28

12. Geologic Rationale for Extensional Basin Framework During Red Dog Mineralization ............32

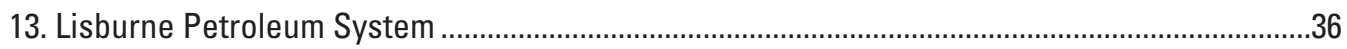

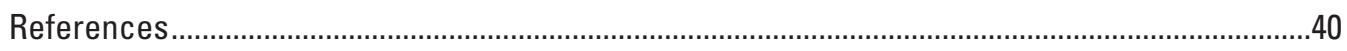

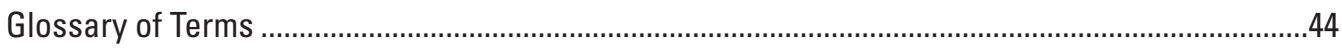




\section{Figures}

1.1. Landsat map of northern Alaska showing location of mineral deposits and occurrences in the western and central Brooks Range and North Slope of Alaska 2

1.2. Grade-tonnage diagram showing data for the Red Dog, Anarraaq, and

Su-Lik deposits compared with those for other deposits worldwide.

2.1. Map of northern Alaksa showing distribution of Lisburne Group rocks

2.2. Depositional setting and stratigraphic context of the Lisburne Group succession in the Red Dog area...

3.1. Plots of organic carbon $\left(\mathrm{C}_{\text {org }}\right)$ versus sulfur $(\mathrm{S})$ for sedimentary rocks .........................7

3.2. Chondrite-normalized rare earth element (REE) plots of altered (silica-rich wall rocks) and mineralized samples from the Red Dog deposits and the Anarraaq deposits

4.1. Stratigraphic column for the central Brooks Range showing locations of barite and sulfide mineral deposits

4.2. Schematic diagram illustrating relative stratigraphic positions of sulfide and barite deposits in northern Alaska.

4.3. Photos of textures of ore types in northern Alaska .......................................................11

5.1. Schematic paleogeography of the Red Dog area in Late Carboniferous .....................13

5.2. Reflux brine model for the shale-hosted massive sulfide deposits, northern Alaska

6.1. Whole rock geochemistry of mineralized, visually unaltered, and unmineralized samples in and around massive sulfide and vein-breccia deposits and occurrences

6.2. Shaded relief map of the Drenchwater area showing stream sediment geochemical anomalies

7.1. Plots of oxygen versus sulfur isotope compositions for Red Dog and central Brooks Range barite deposits

7.2. Histograms of sulfur isotope compositions for barite samples from Red Dog and the central Brooks Range, comparing barite-only to barite associated with sulfides

8.1. Lead isotope diagram for sulfides from Red Dog and from the Brooks Range.

8.2. Initial strontium isotope ratios of barite from the Red Dog deposits, Anarraaq and other deposits or occurrences in the Red Dog district, and from regional deposits or occurrences east of Red Dog in the western and central Brooks Range.

9.1. Outcrop and hand sample photographs of phosphorite occurrences in northern Alaska

9.2. Palinspastic restoration of northern Alaska showing location of phosphatic strata surrounding the Kuna Basin

10.1. Shaded relief map of the Howard Pass quadrangle showing locations of oil shale and tasmanites sampled during 2005.

10.2. Outcrop photographs of oil shale occurrences.

11.1. Map showing major structures and structural units and location of cross section. 
11.2. Cross section from Kugururok River to Tupikchak Creek, Misheguk

Mountain and De Long Mountains quadrangles.

12.1. Schematic northwest to southeast cross section depicting the Anarraaq deposit in Late Mississippian time ..............................................................................33

12.2. Geologic cross section through the Red Dog district ...................................................34

12.3. Interpreted segment of composite reflection seismic line R1 from National Petroleum Reserve-Alaska, approximately $70 \mathrm{~km}$ north-northeast of Red Dog

13.1. Location map of northern Alaska showing distribution of deep- and shallow-water facies of the Lisburne Group, location of North Slope wells, and location of samples used for geochemical analysis 37

13.2. Photomicrographs of dead oil that show evidence for petroleum migration.................38

13.3. Frequency distribution diagrams showing CAI (conodont alteration indices) values of samples of Lisburne Group.

\section{Table}

10.1. Metal concentrations in black oil shale and tasmanite from northern

Alaska compared to other metalliferous organic-rich black shale and oil shale localities. 


\section{Introduction}

\author{
By Karen D. Kelley
}

The foothills of the Brooks Range contain an enormous accumulation of zinc $(\mathrm{Zn})$ in the form of zinc sulfide and barium (Ba) in the form of barite in Carboniferous shale, chert, and mudstone (fig. 1.1). Most of the resources and reserves of Zn occur in the Red Dog deposit and others in the Red Dog district; these resources and reserves surpass those of most deposits worldwide in terms of size and grade (fig. 1.2). In addition to zinc and lead sulfides (which contain silver, $\mathrm{Ag}$ ) and barite, correlative strata host phosphate deposits (fig. 1.1). Furthermore, prolific hydrocarbon source rocks of Carboniferous and Triassic to Early Jurassic age generated considerable amounts of petroleum that may have contributed to the worldclass petroleum resources of the North Slope.

Deposits of $\mathrm{Zn}-\mathrm{Pb}-\mathrm{Ag}$ or barite as large as those in the Brooks Range are very rare on a global basis and, accordingly, multiple coincident favorable factors must be invoked to explain their origins. To improve our understanding of these factors and to contribute to more effective assessments of resources in sedimentary basins of northern Alaska and throughout the world, the Mineral Resources Program and the Energy Resources Program of the U.S. Geological Survey (USGS) initiated a project that was aimed at understanding the petroleum maturation and mineralization history of parts of the Brooks Range that were previously poorly characterized. The project, titled "Regional Fluid Flow and Basin Modeling in Northern Alaska," was undertaken in collaboration with industry, academia, and other government agencies. This Circular contains papers that describe the results of the recently completed project. The studies that are highlighted in these papers have led to a better understanding of the following:

- The complex sedimentary facies relationships and depositional settings and the geochemistry of the sedimentary rocks that host the deposits (sections 2 and 3).

- The factors responsible for formation of the barite and zinc deposits (sections 4 and 5).
- The geochemical indicators or exploration tools that might be used to locate other large deposits of similar character in the Red Dog district and elsewhere (section 6).

- The isotopic compositions of barite and sulfide deposits (sections 7 and 8)

- The distribution and nature of phosphate and metalliferous oil shale localities (sections 9 and 10).

- The architecture, kinematics, and timing of the complex thrust systems that disrupted and redistributed the Carboniferous and younger rocks; these studies are necessary in order to make a realistic palinspastic reconstruction of the basin (sections 11 and 12).

- The nature and extent of the petroleum system sourced from Mississippian rocks (section 13).

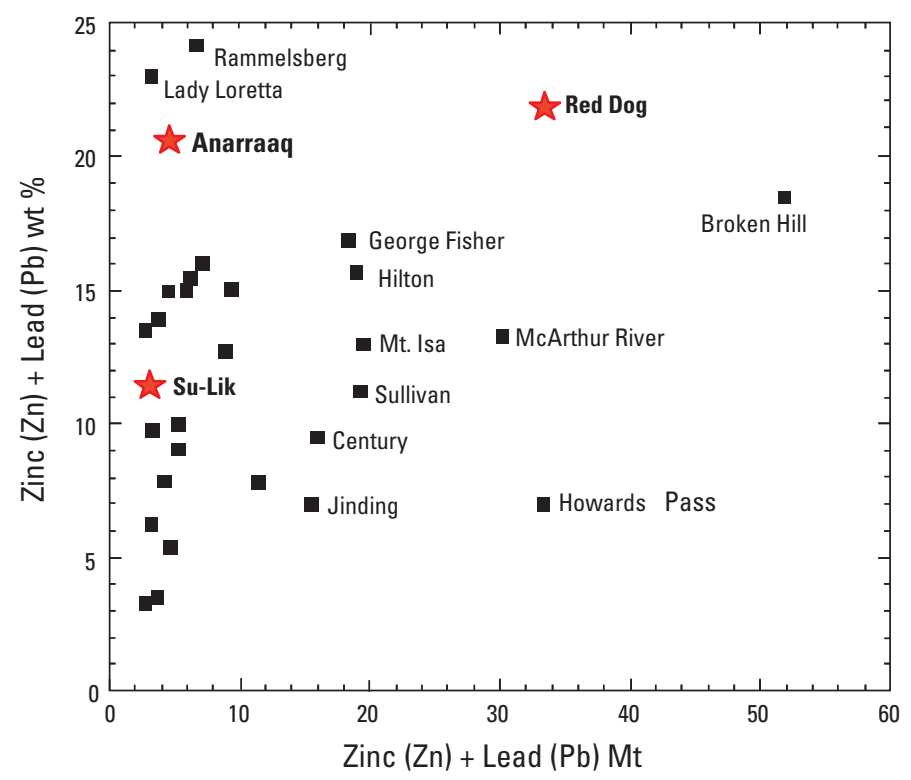

Figure 1.2. Grade-tonnage diagram showing data for the Red Dog, Anarraaq, and Su-Lik deposits (indicated by red stars) compared with those for other deposits worldwide (modified from Large and others, 2002). Other deposits with 15 $\mathrm{Mt}$ or greater and (or) high grade (20 wt percent $\mathrm{Pb}$ and $\mathrm{Zn}$ ) are labeled by name. 


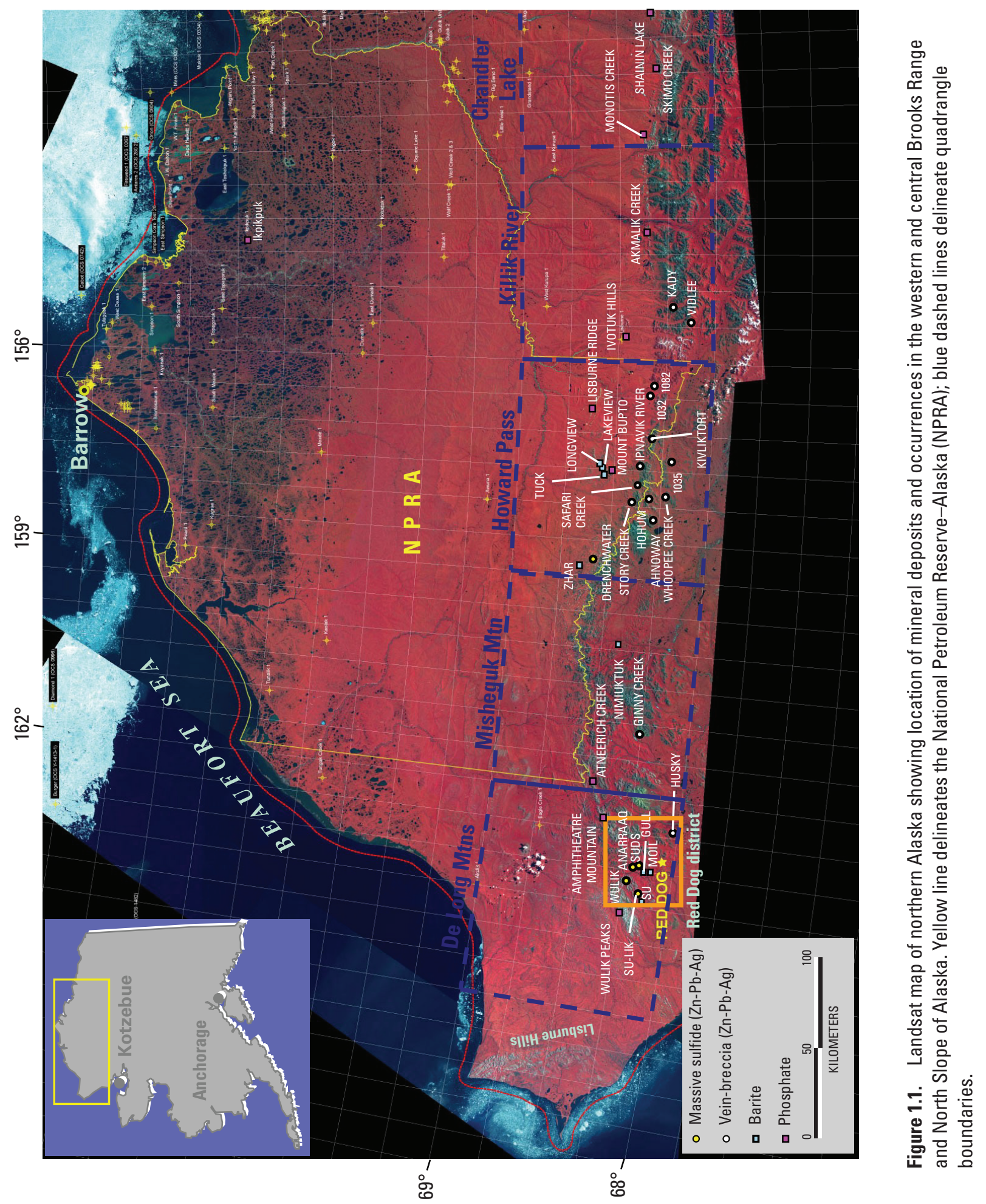




\section{Depositional Settings and Age of Carboniferous Rocks in the Western Brooks Range, Alaska}

\author{
By Julie A. Dumoulin and Anita G. Harris
}

The Kuna Formation of the Lisburne Group (Carboniferous to Permian in age) hosts the giant Red Dog and related $\mathrm{Zn}-\mathrm{Pb}-\mathrm{Ag}$ massive sulfide deposits in northwestern Alaska. The geography of northwestern Alaska at the time of mineralization (about 330 to 340 million years ago) and the nature of the sedimentary basin in which the deposits formed may be determined by comparison of Lisburne Group facies between the Red Dog district and areas farther east (fig. 2.1). Many factors can be considered, including the character and geometry of the basin, the composition of its sediment fill, the timing and environments of deposition within it, and its post-depositional thermal history. All of these factors are important for deciphering the geologic events that led up to and prevailed during mineralization and for assessing where other zinc or barite resources might occur (Dumoulin and others, 2004; Young, 2004).

New studies of the sedimentology and paleontology of the Lisburne Group constrain the setting, age, and thermal history of these deposits. In the west and west-central Brooks Range, the Lisburne Group includes both deep- and shallowwater sedimentary facies and local volcanic rocks that are exposed in a series of thrust sheets or allochthons, which are further subdivided into plates (fig. 2.2). Deep-water facies in the Red Dog area (the Kuna Formation and related rocks) are found chiefly in the Endicott Mountains and structurally higher Picnic Creek allochthons (EMA and PCA, respectively). In the Red Dog plate of the EMA, the Kuna consists of at least $122 \mathrm{~m}$ of thinly interbedded calcareous shale and limestone (Kivalina unit) overlain by $30-240 \mathrm{~m}$ of siliceous carbonaceous shale, mudstone, and limestone including carbonate turbidites (Ikalukrok unit). The Ikalukrok unit in the Red Dog plate hosts all massive sulfide deposits in the area. The Kuna Formation in the Key Creek plate of the EMA $(60-110 \mathrm{~m})$ resembles the Ikalukrok unit but is unmineralized and has thinner carbonate layers that are mainly organic-rich dolostone. Correlative strata in the PCA include less shale and mudstone and more carbonate. Microfossils indicate an age range of Osagian to early Chesterian (late Early-Late Mississippian) for the Kuna in the Red Dog area (fig. 2.2). For explanation of the geologic time scale, refer to Gradstein and Ogg (2004). Sedimentologic, faunal, and geochemical data imply that most of the Kuna formed in slope and basin settings characterized by poorly oxygenated bottom-water and locally high organic productivity.

Shallow-water facies of the Lisburne Group in the Red Dog area occur locally in the EMA and throughout the Kelly River allochthon (KRA) and consist of the Utukok and Kogruk Formations. The Utukok Formation is an impure limestone with disseminated and interbedded noncarbonate mud and quartz-rich silt and sand. Clean carbonate predominates in the overlying Kogruk Formation, but the formation has been widely altered to dolostone and chert. The Utukok Formation is mainly Osagean but its base is Kinderhookian. The Kogruk Formation is mostly Meramecian (early Late Mississippian) in age (fig. 2.2). Most of the rocks of the Kogruk and Utukok Formations were deposited in inner to middle platform settings. Deep-water, locally phosphatic facies of the uppermost Lisburne Group formed during a platform-drowning event of regional extent that began in the late Meramecian.

In the Howard Pass area, approximately $120-250 \mathrm{~km}$ to the east, the Lisburne Group includes an array of shallow- and deep-water facies that correspond well in age and general depositional environment to those in the Red Dog area but differ in some details. Deep-water strata generally are thinner, include less carbonate, and are formed in settings that were deeper and (or) had less detrital input. Shallow-water deposits are less extensive, contain less quartz silt and sand, and are formed chiefly in middle and outer platform settings.

Paleogeographic reconstructions of northern Alaska imply that carbonate platforms flanked the Kuna basin to the north and south in the west, but flourished chiefly north of the basin in the east. The basin shows evidence of periodic tectonic instability and is interpreted as an extensional passive continental margin basin. The platforms provided carbonate and perhaps some noncarbonate detritus to the basin; noncarbonate material could also have come from older strata underlying the platforms and (or) the Endicott delta to the north. Carbonate turbidite deposition in the Kuna basin occurred chiefly during middle Osagean and late Meramecian-early Chesterian (late Early and middle Late Mississippian) times and ceased when adjacent platforms drowned. A combination of local and global factors probably controlled the timing of sediment input to the basin and the flooding of the adjoining carbonate platforms. Platform drowning occurred at about the same time as the start of barite precipitation and sulfide mineralization, implying that regional extension was a significant component of all three events. High productivity, locally thick calcareous turbidite fill, and proximity to restricted, shallowwater carbonate platform environments are aspects of the Kuna basin that appear to have been important in forming the giant Red Dog deposits. 


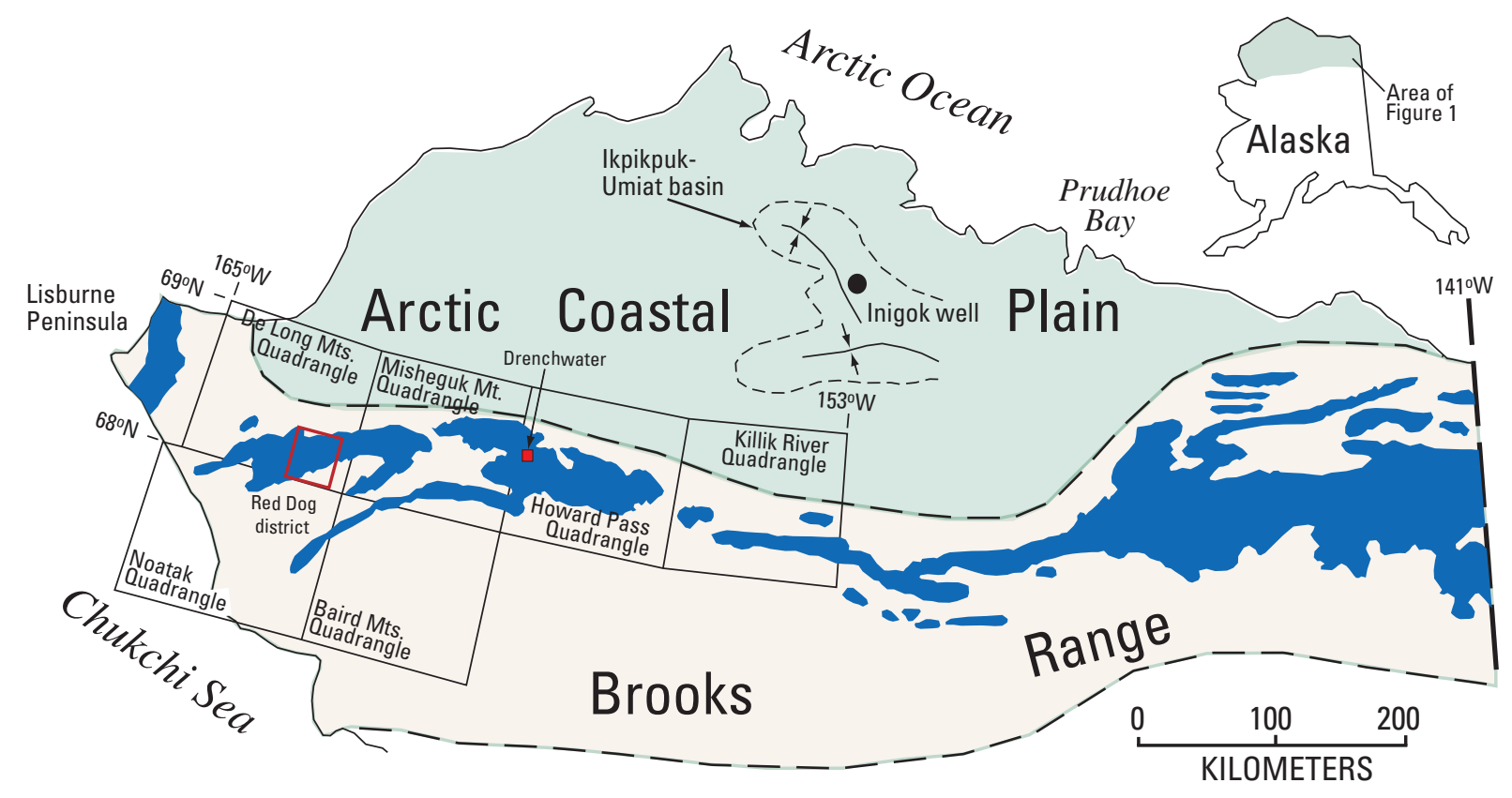

Figure 2.1. Map of northern Alaska showing distribution of Lisburne Group rocks (blue). 


\section{Geochemistry of Paleozoic Sedimentary Rocks: Metallogenic Significance}

\author{
By John F. Slack
}

Whole rock geochemical data provide a basis for interpreting the origin and evolution of Paleozoic sedimentary rocks, not only in the Red Dog region, but regionally throughout the western and central Brooks Range. Such data are useful for identifying hydrocarbon source rocks, establishing critical background values for documenting the geochemistry of hydrothermal alteration in wall rocks to the sulfide deposits of the district, and for discerning the nature and history of fluid flow in the sedimentary basins (Slack, Dumoulin, and others, 2004; Slack, Kelley, and others, 2004).

Concentrations of total organic carbon (TOC) in Paleozoic sedimentary rocks of the region display a large range, but the highest values ( $>4.1 \mathrm{wt}$ percent) occur in black shales of the Kuna Formation, making these potentially important hydrocarbon source rocks. The organic-rich nature of these strata, together with other geochemical attributes, suggest that the geochemistry of the Kuna Formation played a fundamental role in formation of the massive sulfide deposits. A critical factor may have been the anomalously low average $\mathrm{Fe} / \mathrm{Ti}$ (iron/titanium) ratios for shales of the Kuna Formation and Kayak Shale (6.34 and 6.25, respectively), compared to those for other Paleozoic shales in the western Brooks Range and the average of shales worldwide (10.1-10.6). Within most sediments of the Kuna Formation and Kayak Shale, formation of synsedimentary to early diagenetic pyrite was inhibited by the iron-limiting bulk compositions, which resulted in generally low $\mathrm{S} / \mathrm{C}$ (sulfur/carbon) ratios of $<0.2$ (fig. 3.1). These data suggest that in the Kuna basin, reduction of marine sulfate by abundant organic matter and restricted formation of sedimentary pyrite created significant amounts of $\mathrm{H}_{2} \mathrm{~S}$ within anoxic pore fluids. This $\mathrm{H}_{2} \mathrm{~S}$ (hydrogen sulfide) may have been crucial to synsedimentary precipitation of the huge tonnages of base-metal sulfides in the Red Dog district, providing a local source of abundant reduced sulfur in addition to that produced by reduction of seawater sulfate and dissolution of barite (Kelley, Leach, and others, 2004). Distal from sites of $\mathrm{Zn}-\mathrm{Pb}-\mathrm{Ag}$ mineralization, $\mathrm{H}_{2} \mathrm{~S}$ in the sediments of the Kayak Shale and Kuna Formation probably escaped through synsedimentary faults or was removed by diagenetic fluids.

High biological productivity in Mississippian seawater also may have indirectly influenced subseafloor hydrothermal fluid flow and $\mathrm{Zn}-\mathrm{Pb}-\mathrm{Ag}$ mineralization in the Red Dog district. The upper part ofthe Kuna Formation is very siliceous and contains abundant organic carbon and phosphate and locally abundant radiolarians (Dumoulin and others, 2004), all of which are hallmarks of high biological productivity in marine sediments. If these siliceous units became lithified during sedimentation or very early diagenesis, they could have served as effective hydrologic seals or cap rocks to ascending hydrothermal fluids, not only on a district scale but regionally as well. Such cap rocks, if not breached by synsedimentary faults, also would have partly contained the thermal flux associated with mineralization. This process might have helped focus $\mathrm{Zn}-\mathrm{Pb}$ mineralization within permeable carbonate units (for example, calcareous radiolarites), which occur stratigraphically below the black cherts and generally below the bedded siliceous rocks of the Kuna Formation.

Textural and geochemical data record the effects of diagenetic and (or) hydrothermal fluid flow in some of the Paleozoic rocks. Mobility of phosphorus $(\mathrm{P})$, fluorine $(\mathrm{F})$, uranium (U), and light rare earth elements (REEs) is documented in unmineralized black shales of the Kuna Formation by phosphate replacements of carbonate clasts. A negative cerium $(\mathrm{Ce})$ anomaly (see shaded region, fig. 3.2A, $B$ ) for phosphoruspoor black shales of the Kuna Formation suggests that the diagenetic fluids were oxidizing. Other trace elements that document the history of hydrothermal fluid flow that produced wall rock alteration adjacent to the sulfide deposits include thallium ( $\mathrm{Tl})$, antimony $(\mathrm{Sb})$, arsenic (As), germanium (Ge), and positive europium anomalies $\left(\mathrm{Eu} / \mathrm{Eu}^{*}\right)$, reflecting enrichment of europium relative to other rare earth elements (Slack, Kelley, and others, 2004). The latter suite of elements provides a powerful means of distinguishing unaltered and unmineralized rocks from those that were affected by the mineralizing hydrothermal fluids, including altered wall rocks (fig. 3.2A, B) and highly mineralized zones (fig. 3.2C). 

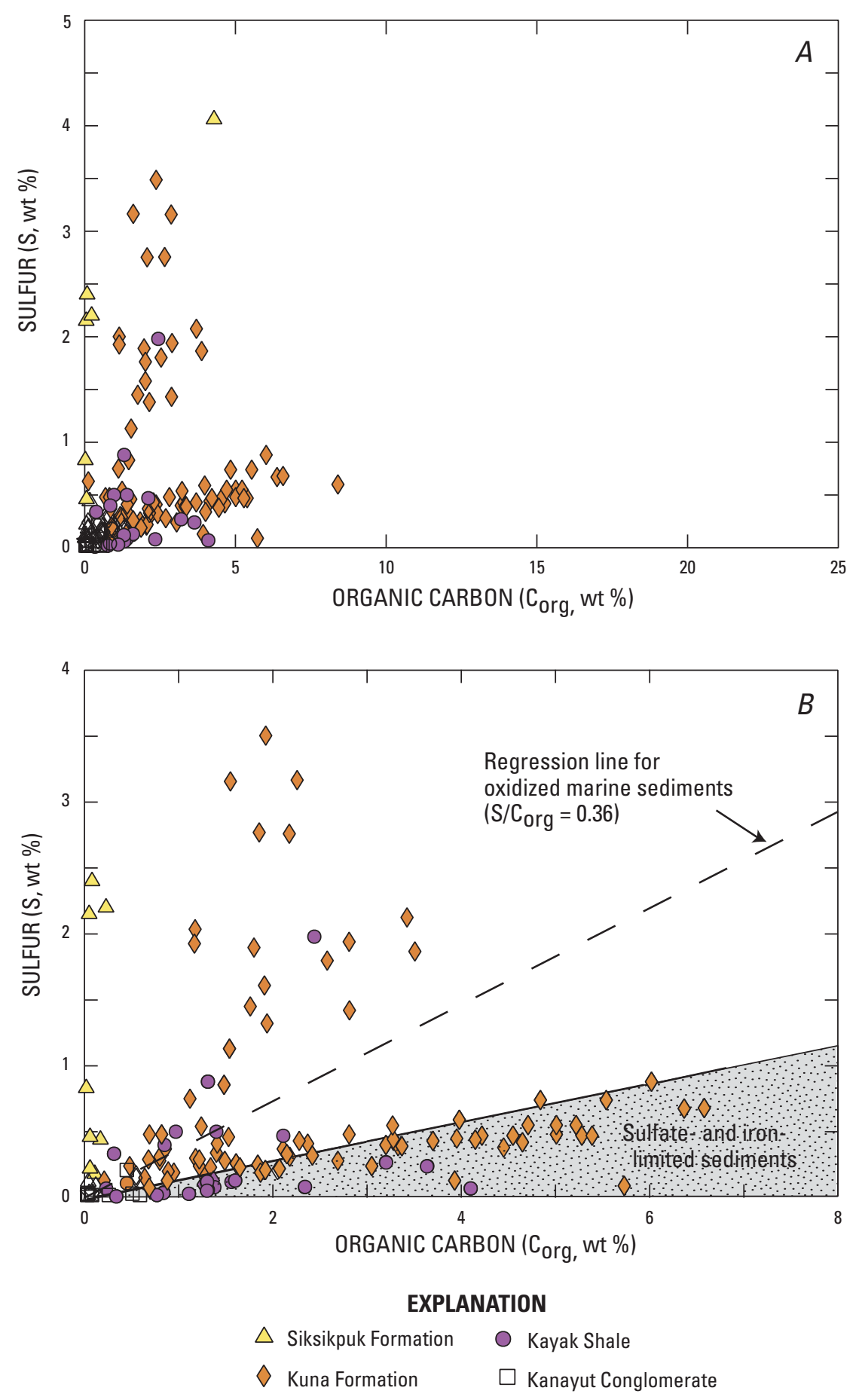

Figure 3.1. Plots of organic carbon $\left(C_{\text {org }}\right)$ vs. sulfur $(S)$ for sedimentary rocks. $A$, Paleozoic and Mesozoic rocks from northern Alaska. $B$, Detail of $A$ showing field for sulfate- and iron-limited sediments. The low iron of most Kuna Formation samples limited the amount of pyrite that formed and increased the amount of sulfur available to form zinc- and lead- sulfide minerals. Modified from Slack and others (2004a). 

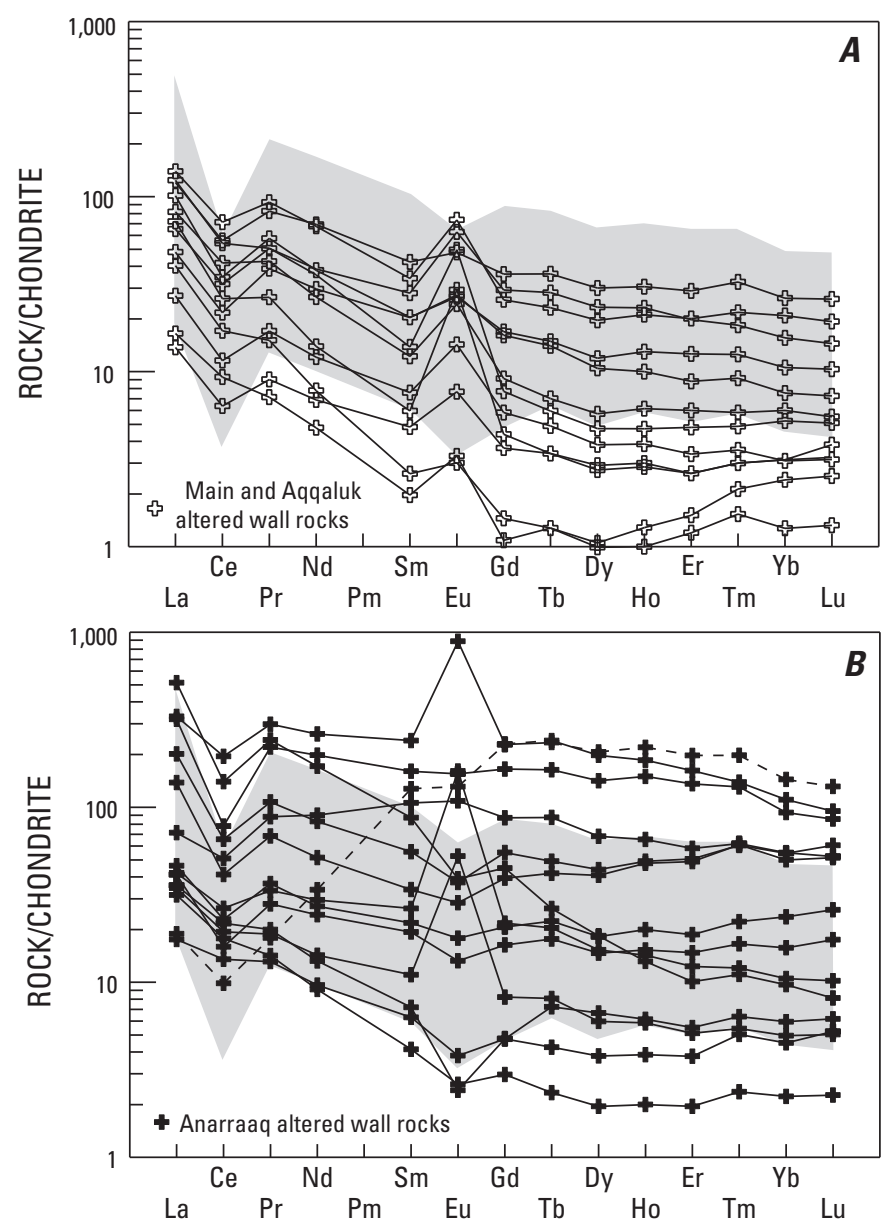

Figure 3.2. Chondrite-normalized rare earth element (REE) plots of altered (silicified wall rocks) and mineralized samples from the Red Dog deposits (Main and Aqqaluk) and the Anarraaq deposit. Unaltered black shales of the Kuna Formation are shown as the shaded field. [Element abbreviations: La, lanthanum; Ce, cerium; Pr, praseodymium; $\mathrm{Nd}$, neodymium; Pm, promethium; Sm, samarium; Eu, europium; Gd, gadolinium; Tb, terbium; Dy, dysprosium; Ho, holmium; Er, erbium; Tm, thulium; Yb, ytterbium; Lu, lutetium]

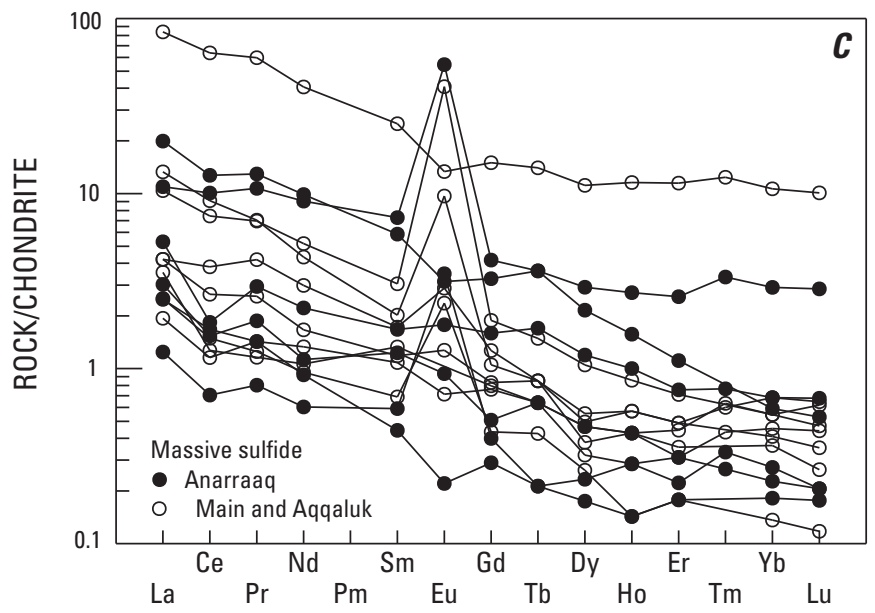




\section{Depositional Models for Barite and Zinc}

\author{
By Karen D. Kelley
}

Understanding the timing and nature of mineralizing processes in northern Alaska allows a better context for relating the mineralizing event to the evolution of the basin, which ultimately increases our ability to assess the potential for similar deposits in other sedimentary basins. Barite and Zn$\mathrm{Pb}-\mathrm{Ag}$ deposits are regionally widespread in northern Alaska (fig. 1.1). Barite occurs as lenses of conformable (parallel to bedding) barite in Mississippian rocks, and disseminated or bladed barite in shale and chert of Pennsylvanian to Triassic age (fig. 4.1). Some deposits are extraordinarily large; for example, barite at the Anarraaq deposit alone is estimated to be as much as 1 billion metric tons (King and others, 2002). Some deposits have both barite and associated sulfides; the sulfide bodies may spatially overlap barite or be separated from barite by unmineralized rock. Other barite deposits lack associated sulfides (fig. 4.2).

The $\mathrm{Zn}-\mathrm{Pb}-\mathrm{Ag}$ mineral occurrences/deposits can be separated into two groups: shale-hosted massive sulfide (SHMS) and $\mathrm{Zn}-\mathrm{Pb}-\mathrm{Ag}$ veins and breccias (termed vein breccias). The SHMS deposits are in the Mississippian Kuna Formation (fig. 4.1) that includes black shale and lesser carbonate layers. Typical of these deposits are mineralized horizons that are laterally extensive (several kilometers to tens of kilometers). The mineralogy of the massive sulfide deposits is a simple assemblage of sphalerite, galena, pyrite, and marcasite. Grain sizes and textures of the ores are highly variable (fig. 4.3), ranging from very fine-grained and layered (parts of Drenchwater, Anarraaq, and Su-Lik) to extremely coarse-grained and fragmental or brecciated (Red Dog deposits). Paragenetic studies of the individual deposits underscore a complex history of formation (Kelley, Dumoulin, and Jennings, 2004; Kelley, Leach, and others, 2004).

The vein breccia occurrences are discordant (cross cut bedding) in clastic sedimentary rocks of the Endicott Group that stratigraphically underlie the Kuna Formation (fig. 4.1 and 4.2). These commonly occur as narrow mineralized veins or vein sets that are not laterally extensive at the surface. The relative proportions of sulfide minerals vary but the dominant sulfide mineral is sphalerite with lesser amounts of galena, pyrite, and chalcopyrite; quartz is the dominant gangue mineral. Textures range from host-rock breccias cemented by sulfides and quartz, to veins with color-banded and (or) crustiform sphalerite with lesser banded quartz, to complex breccias (fig. 4.3).
Chemical and isotopic data, as well as absolute ages, were obtained for deposits in the Red Dog district. The following paragenesis is indicated: (1) deposition of minor sulfides with abundant barite immediately beneath the seafloor in unconsolidated mud-at Anarraaq, barite replaced shallow carbonate lenses; (2) subseafloor hydrothermal recrystallization and coarsening of pre-existing barite as a result of introduction of the main ore-bearing fluid; and (3) open-space deposition of barite and sulfides in veins and coeval replacement of barite-at Anarraaq, replacement of carbonate was the dominant process of sulfide deposition (Kelley, Dumoulin, and Jennings, 2004; Kelley, Leach, and others, 2004).

Geochemical and isotopic characteristics suggest that the vein-breccia occurrences are the remnants of hydrothermal fluid flow in the clastic aquifer. These fluids ascended along faults and formed the overlying SHMS deposits (Young, 1989; Kelley and others, 2000; Ayuso and others, 2004). An alternative explanation is that the vein breccias formed along faults during the Mesozoic Brookian orogeny, as some vein zones parallel fold axes of anticlines (Ellersieck and others, 1982; Kurtak and others, 1995), and galena at the Vidlee occurrence shows curvature of crystal cleavages. However, other veins (for example, Kady) terminate at Mesozoic thrust faults (Werdon, 1999), and ${ }^{40} \mathrm{Ar} /{ }^{39} \mathrm{Ar}$ (argon) isotopic dating of recrystallized detrital white mica in sandstone adjacent to a mineralized quartz vein at Kady yields an age of $324 \mathrm{Ma}$ (Werdon and others, 2004). In addition, lead isotope compositions of galenas from the vein breccias are within the range of compositions in the overlying shale-hosted sulfide deposits, suggesting that the lead in both types of deposits was derived from a similar or perhaps common crustal reservoir and are of similar age (Young, 1995; Ayuso and others, 2004; Werdon and others, 2004). If the veins were significantly younger, radiogenic growth of lead would be reflected in the lead isotope ratios of galena from the vein breccias.

An absolute age for the SHMS deposits was determined by Re-Os (rhenium-osmium) isotopic methods to be $338.3 \pm$ 5.8 Ma (Morelli and others, 2004). This age overlaps the age of minor igneous rocks in the area (Werdon and others, 2004) and the age of the host rocks (Dumoulin and others, 2004). Based on similar stratigraphic positions, it is inferred that barite and phosphate formed coevally with the zinc deposits (Dumoulin and others, 2006). The stratigraphic and textural information, together with age data, suggest that the initiation of barite, phosphate, and zinc mineralization coincided with regional drowning of the outboard carbonate platform in Late Mississippian time, presumably as a result of extensional tectonism and subsidence along a passive continental margin. 


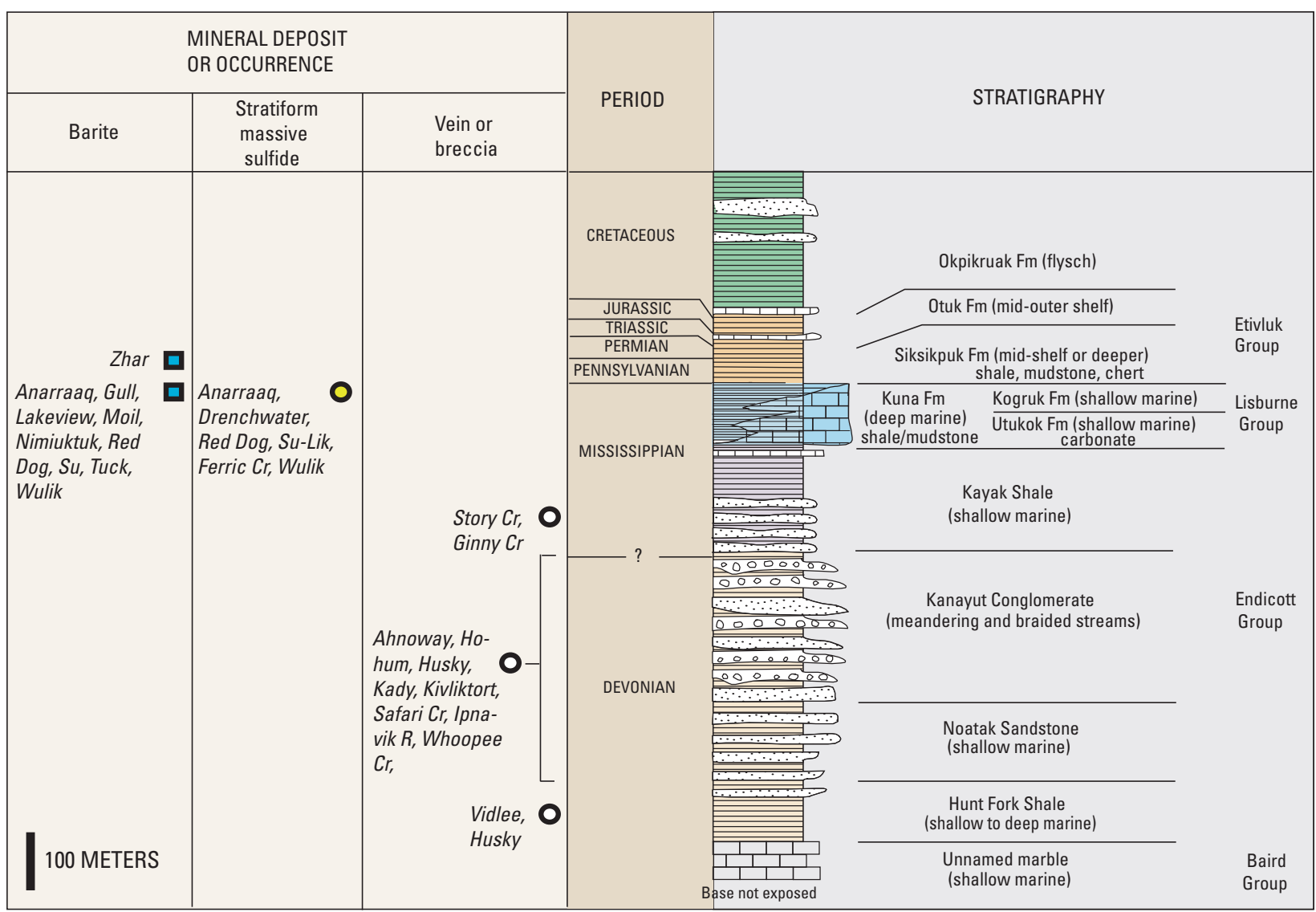

Figure 4.1. Stratigraphic column for the central Brooks Range showing locations of barite and sulfide mineral deposits (modified from Moore and others, 1994; Young, 2004). For locations of deposits, see figure 1.1.

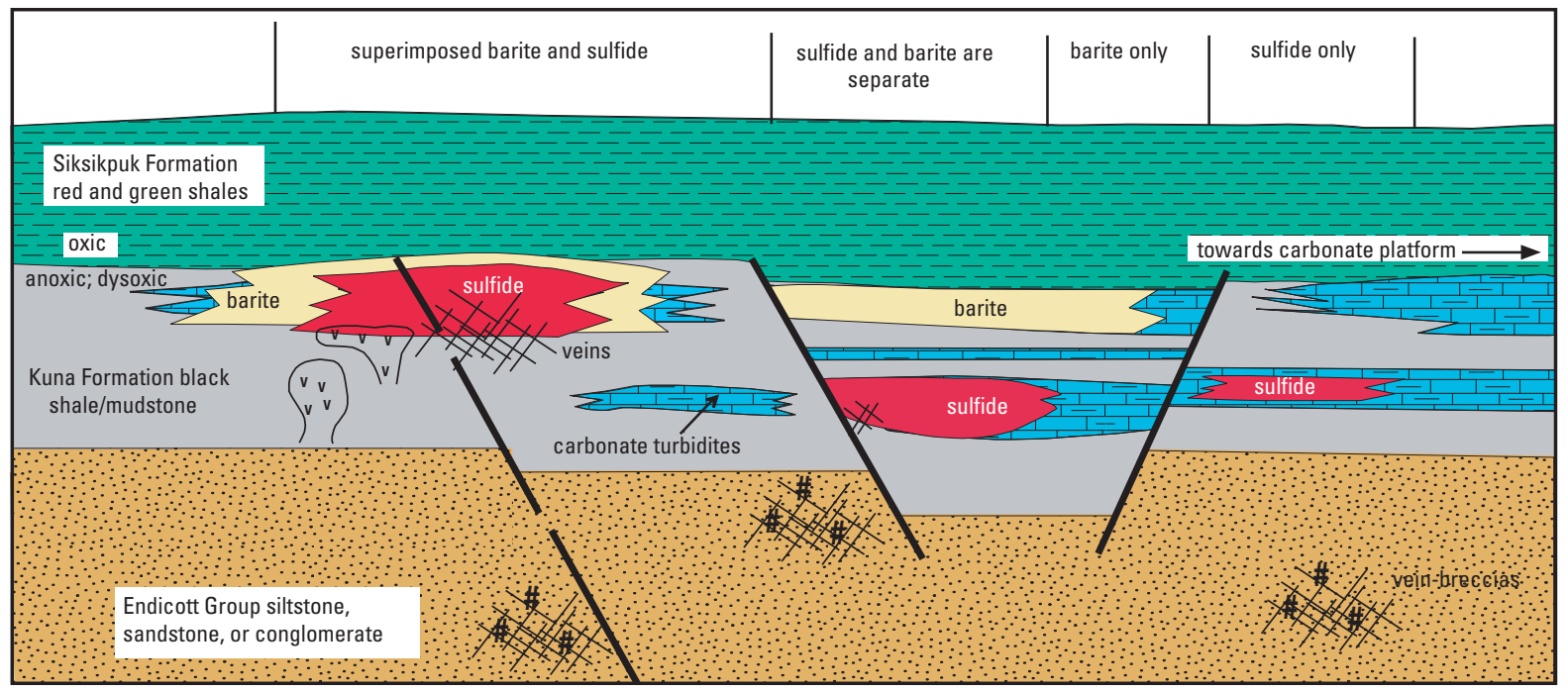

Figure 4.2. Schematic diagram illustrating relative stratigraphic positions of sulfide and barite deposits in northern Alaska. Some have superimposed barite and sulfide bodies (for example, Red Dog), some have barite and sulfides that are spatially separated (for example, Anarraaq), some are barite only (Moil, Gull), and some are sulfide only (Su-Lik, Drenchwater). Modified from Kelley and Jennings (2004). 

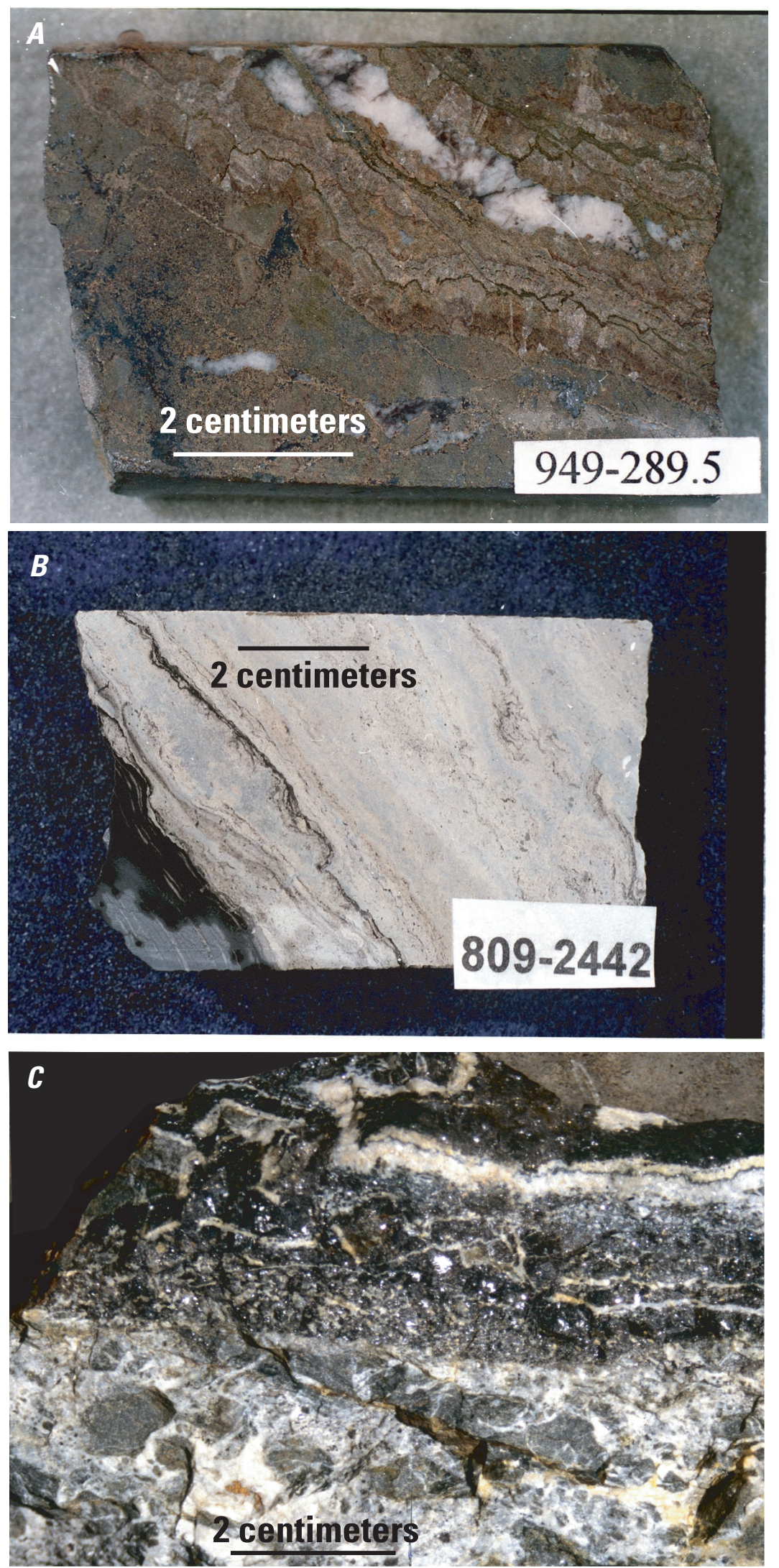

Figure 4.3. Textures of ore types in northern Alaska. $A$, Vein ore from Red Dog. $B$, Banded ore from Anarraaq. Cream colored mineral is sphalerite. C, Typical vein breccia occurrence (Ahnoway) showing vein with adjacent breccia. 


\section{Insights into the Ore-Forming Fluids}

\section{By David L. Leach}

Investigations of fluid inclusions can provide information on the composition, temperature, pressure, and possible sources of the hydrothermal fluids responsible for ore and gangue minerals. In a broader sense, this information contributes to a better understanding of why and where such giant deposits form in the Earth's crust.

Fluid inclusions in ore-stage sphalerite and post-ore quartz gangue in the Red Dog deposits were analyzed (Leach and others, 2004). The temperatures of the fluids that deposited the vein sphalerite were probably less than $200^{\circ} \mathrm{C}$ and perhaps as low as $100^{\circ} \mathrm{C}$. The maximum depth of sediment burial during mineralization was not greater than $200 \mathrm{~m}$ based on thickness of the Kuna Formation in the Red Dog area. Therefore, the presence of temperatures of 100 to $<200^{\circ} \mathrm{C}$ during ore deposition less than $200 \mathrm{~m}$ below the seawater-Kuna sediment interface requires locally high thermal gradients.

The origin of these anomalously high temperatures at such shallow depths is equivocal. There is no direct evidence for major igneous intrusions in the vicinity of the Red Dog deposits other than the presence of volumetrically minor altered alkali basalt and rhyolite intrusions. The ${ }^{40} \mathrm{Ar} /{ }^{39} \mathrm{Ar}$ dates of biotite from the altered intrusions overlap a Re-Os date for ore-stage pyrite ( $338 \pm 5 \mathrm{Ma}$ ) and the age of Kuna Formation sedimentation. The presence of a large intrusion below the ore deposits during ore deposition cannot be excluded because the ore deposits were displaced from their location during Mesozoic thrusting. A plausible source of local heating of the Kuna Formation at the Red Dog deposits is avecting hydrothermal fluids that acquired geothermal heat at considerable depth in the underlying rocks. Assuming normal thermal gradients of 25 and $35^{\circ} \mathrm{C}$ per km, with ambient surface temperatures of $15^{\circ} \mathrm{C}$ in the Carboniferous, a temperature of $100^{\circ} \mathrm{C}$ would have required fluid circulation to about 3.4 to $2.4 \mathrm{~km}$ and a temperature of $200^{\circ} \mathrm{C}$ would have required circulation to between 7.4 and $5.3 \mathrm{~km}$.

Final ice melting temperatures indicate that the fluid inclusions in sphalerite have salinities of about 14 to $19 \mathrm{wt}$ percent $\mathrm{NaCl}$ equivalent. The fluid inclusion electrolyte data show that the ore fluid for the vein sphalerite derived its salinity from the evaporation of seawater and has a composition that is indistinguishable from evolved basin brines that formed Mississippi Valley-type (MVT) deposits (Leach and others, 2005). The dissolution of evaporites is inconsistent with the composition of fluid inclusion electrolyte data. Considering the salinity of the vein sphalerite fluid inclusions together with the electrolyte data, the seawater evaporative brine was probably initially about $30 \mathrm{wt}$ percent saline fluid and was diluted by seawater or meteoric water at some point in its flow path. There is evidence for an increasingly arid climate in northern Alaska during the Chesterian (Dumoulin and others, 2004; Young, 2004), a time that was coeval with the age of Red Dog mineralization (see fig. 2.2). The best chance for seawater evaporative environments close to the Red Dog deposits was in the shallow subtidal to supratidal facies of the Lisburne Group (Kogruk Formation) in the Wolverine Creek plate of the Endicott Mountains allochthon, located less than 50 to $75 \mathrm{~km}$ north of the ore deposits prior to Brookian thrusting (fig. 5.1). The proximity of the Red Dog deposits to broadly coeval evaporative environments is consistent with models that call upon infiltration of reflux brines during the precipitation of MVT lead-zinc ores.

Fluid inclusions were also studied in the abundant quartz that constitutes the majority of the silica rock in the ore deposits. This post ore quartz extensively replaced barite and was traditionally thought to be part of the main ore event. Primary fluid inclusion assemblages contain two-phase aqueous inclusions, single-phase inclusions of dense methane, or both. Primary assemblages that contain single-phase, dense methane inclusions together with two-phase aqueous inclusions yield consistent homogenization temperatures and provide unequivocal evidence for the coeval trapping of immiscible gas- and aqueous-rich fluids. The densities of the methane inclusions, together with the temperature of homogenization of coexisting aqueous fluid inclusions, show that these fluid inclusions were trapped between pressures of 800 and 3,400 bars and temperatures between 187 and $214^{\circ} \mathrm{C}$. The pressures obtained provide unequivocal evidence that the quartz formed after ore deposition in the Carboniferous because such high fluid pressures could only have been produced from thrust loading during the Mesozoic Brookian orogeny. The observed large variation in pressure is best explained by transient fluid pressures from hydrostatic to lithostatic conditions during thrust loading. The 3,400 bars pressure corresponds to about $12 \mathrm{~km}$ of lithostatic burial, whereas the lower pressure ( 800 bars) correspond to about $8 \mathrm{~km}$ of hydrostatic pressure. Because of their low salinity ( 0 to $5 \mathrm{wt}$ percent $\mathrm{NaCl}$ equivalent) the electrolyte compositions of the quartz fluid inclusions do not constrain their origin(s).

This study provides the first direct fluid inclusion data on the origin of the ore fluids for deposits of this type and yields insights into the hydrothermal fluid processes that produced this world-class ore deposit. Furthermore, the data show that most of the silica present in the ore deposits is unrelated to the ore-forming event. Thus, the presence of silica in the host rocks cannot be used as a guide to mineralization. Perhaps the most important conclusion is that the ore fluid was an evolved basin brine that obtained its salinity through the evaporation of seawater. These brines were probably sourced by supratidal carbonate rocks of the Lisburne Group, infiltrated into the 
underlying rocks of Endicott Group, and extracted metal from rock-water reactions within the sandstone and conglomerate aquifers or the underlying metasedimentary basement rocks (fig. 5.2). In the Red Dog area, the metalliferous fluids ascended into the organic-rich rocks of the Kuna Formation along zones of active extensional faults or breaches in the shale aquitards overlying the aquifers in Endicott Group. The mechanisms for ore deposition at the Red Dog deposits are not established but probably involved a combination of fluid mixing, fluid-rock reactions that include reduction of barite, or cooling. Studies show that brine infiltration from evaporative environments in carbonate platforms produces temperatures, flow rates, and duration of the reflux system sufficient to explain ore formation in the passive margin. Since the brine infiltration model calls upon a continued brine recharge into underlying rocks and aquifers, it could produce a protracted period of mineralization and potentially giant ore deposits such as the Red Dog deposits. The genesis of shale-hosted ores like the Red Dog deposits may be most favorable in siliciclastic-starved, shale and organic-rich passive margin sub-basins, that are flanked by carbonate platforms that contain evaporative sabka-like environments. Furthermore, the important carbonate turbidite fill in many passive margin settings that contain flanking carbonate platforms may also be an important control in localizing the ore into permeable and chemically reactive lithologies.

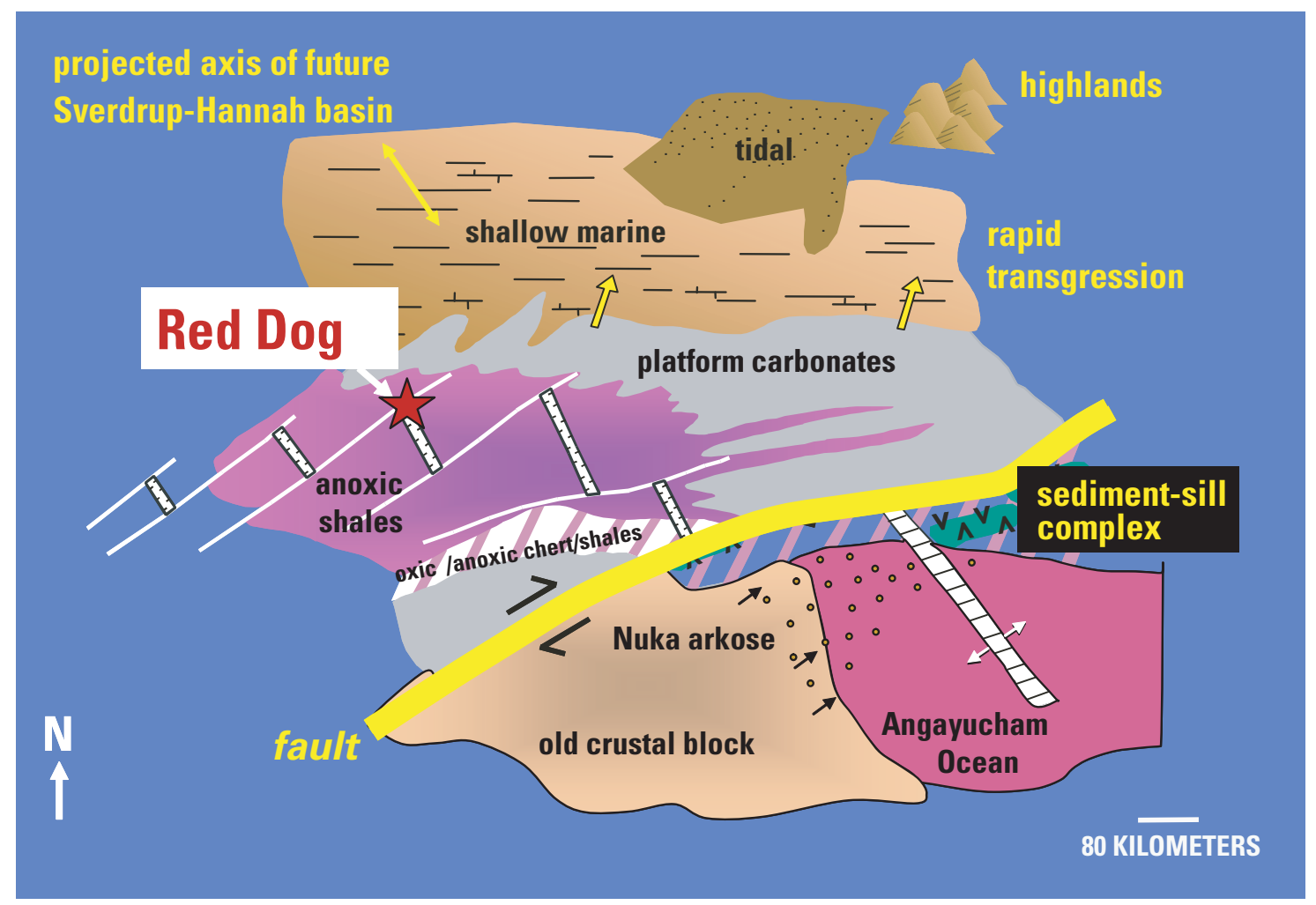

Figure 5.1. Schematic paleogeography of the Red Dog area in Late Carboniferous (modified from Young, 2004). A possible source for the evaporatively concentrated seawater (brines) for the ore fluids was a sabkha-like environment north of Red Dog. The brines infiltrated fluvial-deltaic rocks and extracted metal from sandstone and conglomerates. The fluids ascended into organic-rich rocks of the Kuna Formation along zones of active extensional faults. 


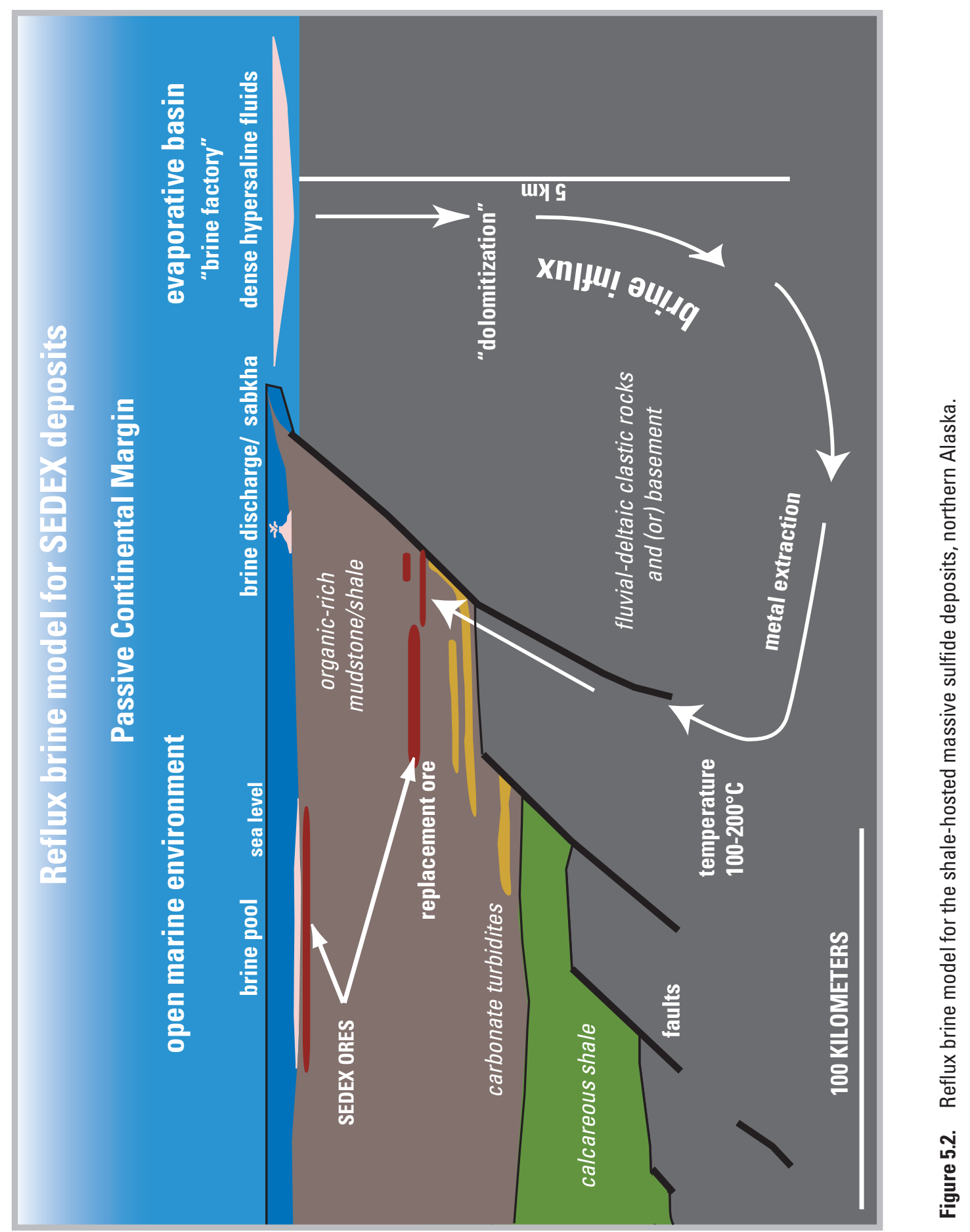




\section{Geochemical Indicators of Massive Sulfide Deposits and Vein Breccia $\mathrm{Zn}-\mathrm{Pb}-\mathrm{Ag}$ Occurrences}

\author{
By Garth E. Graham, Karen D. Kelley, and John F. \\ Slack
}

Geochemical anomalies in regional stream sediment samples played a significant role in locating the Red Dog deposit (Tailleur, 1970) and other shale-hosted massive sulfide (SHMS) deposits in the Red Dog district, as well as the Drenchwater deposit (Jansons, 1982) and numerous vein breccia occurrences (Duttweiler, 1987; Meyer and Kurtak, 1992; Kelley and others, 1997). However, the limited suite of elements determined and the relatively high detection limits of some analytical methods made it difficult to distinguish the SHMS deposits from the vein breccia occurrences by an evaluation of regional geochemical data. Furthermore, all of the deposits and occurrences listed above are at least partly exposed at the surface, and therefore, sulfide and gangue minerals were affected by surface weathering (mechanical and chemical) and oxidation processes. In these environments, elements such as lead $(\mathrm{Pb})$ and zinc $(\mathrm{Zn})$ behave in a predictable manner (that is, $\mathrm{Pb}$ is relatively immobile compared to $\mathrm{Zn}$ ), allowing for a straightforward interpretation of the stream sediment data. In contrast, if the deposits are concealed, the mobility and transport of elements may differ, and elements other than $\mathrm{Pb}$ or $\mathrm{Zn}$ may be as good or better pathfinder elements for these deposits.

Using modern analytical techniques, geochemical studies were recently undertaken to (1) determine element associations that distinguish these two types of deposits, and (2) highlight pathfinder elements that have not traditionally been used to delineate SHMS-type deposits. These data allow us to assess the resource potential of an area with more certainty. Analyses of whole rock and stream sediment samples from SHMS and vein breccia occurrences show that both deposit types yield similar geochemical signatures with regard to most elements including zinc $(\mathrm{Zn})$, lead $(\mathrm{Pb})$, silver $(\mathrm{Ag})$, arsenic
(As), and antimony (Sb) (Slack, Kelley, and others, 2004; Graham and others, in press). Results show: (1) in addition to $\mathrm{Pb}$ and $\mathrm{Zn}$, most mineralized samples from the SHMS deposits contain anomalously high concentrations of As ( $>40$ to 672 ppm), germanium (Ge; $>2$ to $823 \mathrm{ppm}$ ), $\mathrm{Sb}$ (>12 to $919 \mathrm{ppm}$ ), and thallium ( $\mathrm{Tl} ;>1.5$ to $313 \mathrm{ppm}$ ); (2) Tl shows the greatest range in concentration and is consistently elevated in mineralized rocks and altered (but unmineralized) rocks adjacent to the SHMS deposits; and (3) geochemical differences between the two deposit types include low $\mathrm{Tl}(<0.7 \mathrm{ppm})$ and elevated copper ( $\mathrm{Cu} ; 260$ to 2,450 ppm) and gold (Au; 200 to1,010 $\mathrm{ppb}$ ) in the vein breccia occurrences compared to the SHMS deposits (fig. 6.1). These differences provide a powerful means of distinguishing the SHMS from the vein breccia occurrences.

Geochemical data for sediment samples from streams draining the SHMS and vein breccia deposits mimic the whole-rock patterns described above. In particular, stream sediment samples from drainages near the SHMS deposits contain anomalously high concentrations of $\mathrm{Tl}(>1.3 \mathrm{ppm})$ compared to those near the vein breccia occurrences (approximately 0.5 to $0.8 \mathrm{ppm}$ ). Soil samples collected over buried portions of the Su-Lik deposit also show elevated Tl directly over the ore body (Kelley and Kelley, 2003).

Results of a stream sediment survey at Drenchwater show that uranium $(\mathrm{U})$ and phosphorus $(\mathrm{P})$ concentrations are anomalously high (7.1 to $18.1 \mathrm{ppm}$ and 1,500 to $4,040 \mathrm{ppm}$, respectively) in some samples draining known mineralized areas (fig. 6.2). These elements, and mercury ( $\mathrm{Hg}$ ), molybdenum (Mo), and selenium (Se), are also elevated in soil samples at the Su-Lik deposit (Kelley and Kelley, 2003), suggesting that $\mathrm{Tl}, \mathrm{U}, \mathrm{P}, \mathrm{Hg}, \mathrm{Mo}$, and Se may be additional pathfinder elements for SHMS deposits (Graham and others, in press).

The element associations that delineate the Drenchwater deposit are also characteristic of stream sediments from Twistem Creek and the Kiligwa River east of Drenchwater (fig. 6.2), as well as from Spike Creek, about $130 \mathrm{~km}$ west of Drenchwater. These data suggest that there is potential for additional undiscovered SHMS resources in these areas. 
A.

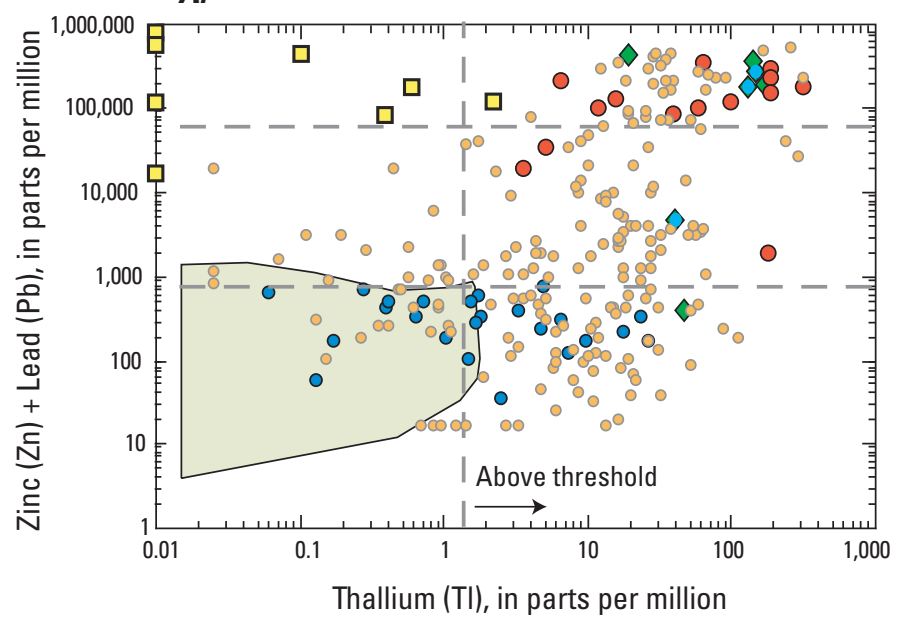

C.

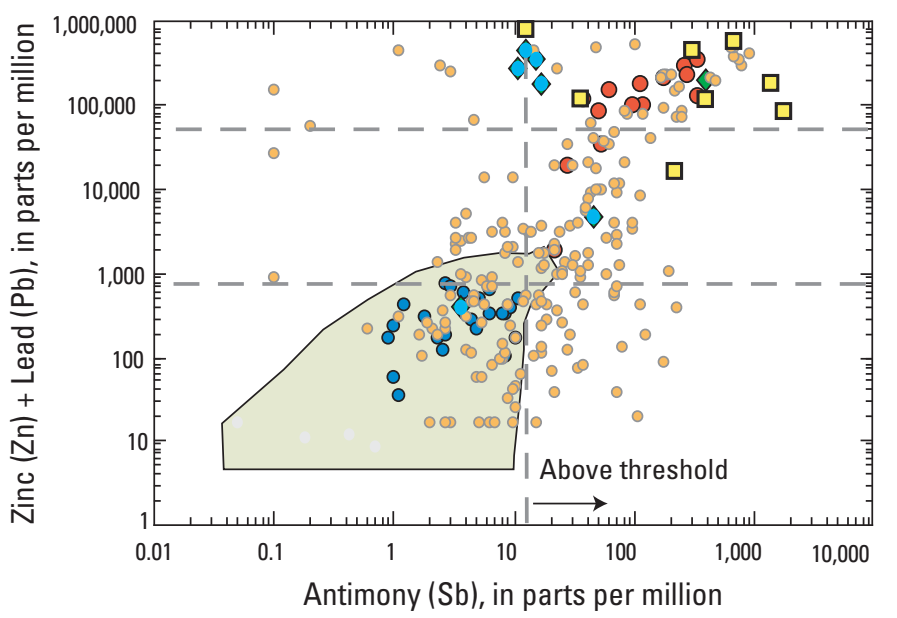

B.

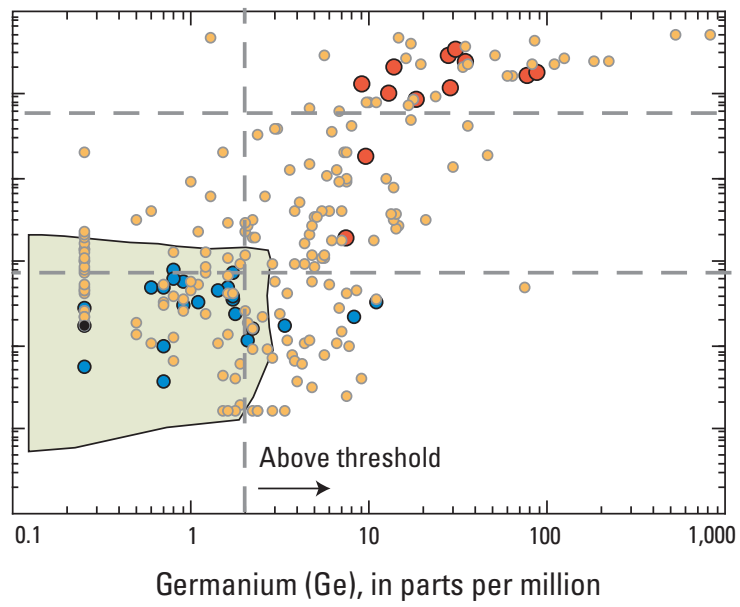

D.

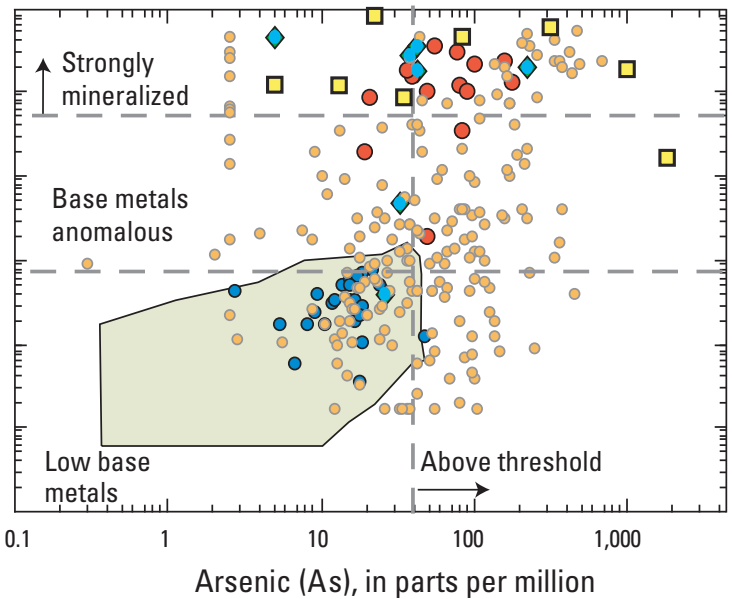

EXPLANATION

- Red Dog and Anarraaq $\bigcirc$ Drenchwater $\diamond$ Su-Lik $\square$ Vein breccia $\quad$ Visually unaltered

$\bigcirc$ Range ofunmineralized samples

Figure 6.1. Whole rock geochemistry of mineralized, visually unaltered, and unmineralized samples in and around massive sulfide and vein-breccia deposits and occurrences. $A$, thallium; $B$, germanium; $C$, antimony; $D$, arsenic. 

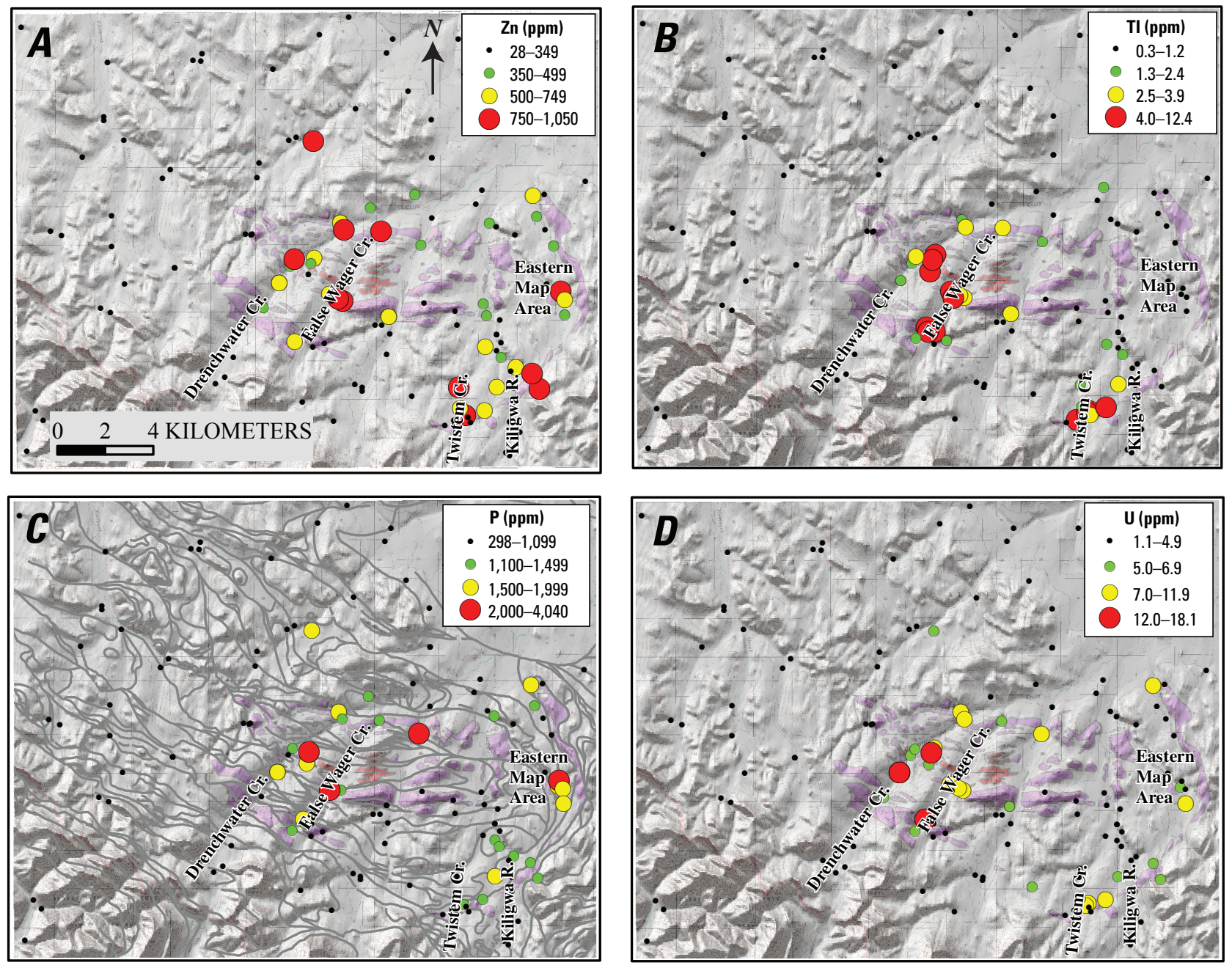

Figure 6.2. Shaded relief map of the Drenchwater area showing stream sediment geochemical anomalies. Purple shaded regions are outcrop areas of the Kuna Formation. Main sulfide outcrop is indicated; however, disseminated sulfides occur along northwest-southeast zone between Drenchwater and False Wager Creeks. $A$, Zinc $(\mathrm{Zn})$ content in parts per million (ppm). $B$, Thallium (TI) content in ppm. $C$, Phosphorus (P) content in ppm.

$D$, Uranium (U) content in ppm. 


\section{Sulfur and Oxygen Isotope Chemistry of Barite}

\section{By Craig A. Johnson}

Barite deposits are numerous in northern Alaska (fig. 1.1) and many are associated with sulfide mineralization. In the Red Dog district, the sulfides are either intergrown with the barite (for example, Red Dog deposits) or they occur as separate bodies in stratigraphically underlying rocks (for example, the Anarraaq deposit, fig. 4.2). In the Howard Pass quadrangle of the central Brooks Range, sulfide mineralization has not been recognized intergrown with the barite deposits (fig. 1.1), but whether or not separate sulfide bodies are concealed beneath the outcropping barite is unknown. Tools for determining the presence of underlying sulfides beneath the barite deposits would help assess the potential for concealed $\mathrm{Zn}-\mathrm{Pb}$ $\mathrm{Ag}$ sulfide mineralization.

Johnson and others (2004) suggested that barite-only mineralization (that is, barite that has no associated sulfides) might be distinguished from barite associated with lead-zincsilver deposits by analyzing sulfur- and oxygen isotopes in the barite. Results are reported in $\delta$ notation, where $\delta=\left[\left(\mathrm{R}_{\text {Sample }}{ }^{\prime}\right.\right.$ $\mathrm{R}_{\text {Standard }}$ ) -1$] \times 1,000$, and $\mathrm{R}_{\text {Sample }}$ and $\mathrm{R}_{\text {Standard }}$ are the ratio ${ }^{34} \mathrm{~S} /{ }^{\beta 2} \mathrm{~S}$ or ${ }^{18} \mathrm{O} /{ }^{16} \mathrm{O}$ in sample and standard, respectively. Analyses from the Red Dog district suggest that a typical barite-only deposit (Anarraaq) shows tight $\delta^{18} \mathrm{O}$ vs. $\delta^{34} \mathrm{~S}$ correlations extending from the isotopic composition of seawater sulfate in Mississippian time to very high $\delta$-values. By contrast, barite associated with sulfide mineralization at the Red Dog mine shows a poorer $\delta^{18} \mathrm{O}$ vs. $\delta^{34} \mathrm{~S}$ correlation with $\delta^{18} \mathrm{O}$ values that are equal to or below seawater sulfate (fig. 7.1A).

Outcropping barite deposits of the Howard Pass quadrangle show fairly tight arrays on a $\delta^{18} \mathrm{O}$ vs. $\delta^{34} \mathrm{~S}$ plot (fig. 7.1B). Linear regression slopes range from 1 to 5 , much like the slopes that characterize Anarraaq and other barite-only deposits in the Red Dog district. The isotopic variations reflect barite precipitation from combinations of seawater sulfate, which had been isotopically enriched by bacterial sulfate reduction, and sulfate from reoxidation of the bacteriallyproduced $\mathrm{H}_{2} \mathrm{~S}$.

The Howard Pass barites are compared with Red Dog district barite-zinc-lead-silver deposits and Red Dog bariteonly deposits in figure 7.1C. The Howard Pass barites differ from Red Dog district barite-only deposits in that they lack very high $\delta$-values and show $\delta^{18} \mathrm{O}$ values equal to or less than the value for Mississippian seawater sulfate. Both observations suggest a closer affinity to sulfide-associated barite than to barite-only mineralization.

Histogram plots (fig. 7.2) show that the Howard Pass $\delta^{34} S$ distribution resembles the distribution for Red Dog district barite-zinc-lead-silver deposits; most notably both lack very high $\delta^{34} S$ values. However, the Howard Pass distribution is displaced to higher $\delta^{34} \mathrm{~S}$ by about 3 per mil. If the Howard Pass and Red Dog mineralizations formed simultaneously, as the stratigraphic correlations imply, then the $\delta^{34} \mathrm{~S}$ difference implies that Howard Pass barite formed in a basin that was isolated from the larger Mississippian basin, or that the Red Dog and Howard Pass deposits formed in different isolated basins.

Barite associated with Red Dog district $\mathrm{Zn}-\mathrm{Pb}-\mathrm{Ag}$ deposits formed where seawater sulfate was bacterially reduced and then reoxidized at a rate that was fast compared to the rate of supply of fresh sulfate. This condition would be consistent with stagnant basin waters. Stagnation favors anoxia, which can ultimately lead to the accumulation of $\mathrm{H}_{2} \mathrm{~S}$, an essential ingredient for the formation of $\mathrm{Zn}-\mathrm{Pb}-\mathrm{Ag}$ sulfide mineralization. Thus, the sulfur and oxygen isotope data for the Howard Pass barite occurrences record conditions that would have been favorable for the later formation of zinc-lead-silver s ulfide deposits, and the preservation of these deposits in the rock record. The other essential ingredient for sulfide deposits is a supply of metals. Whether zinc, lead, silver, and other metals were available during formation of the Howard Pass barite is a question on which the stable isotope data have no direct bearing. 

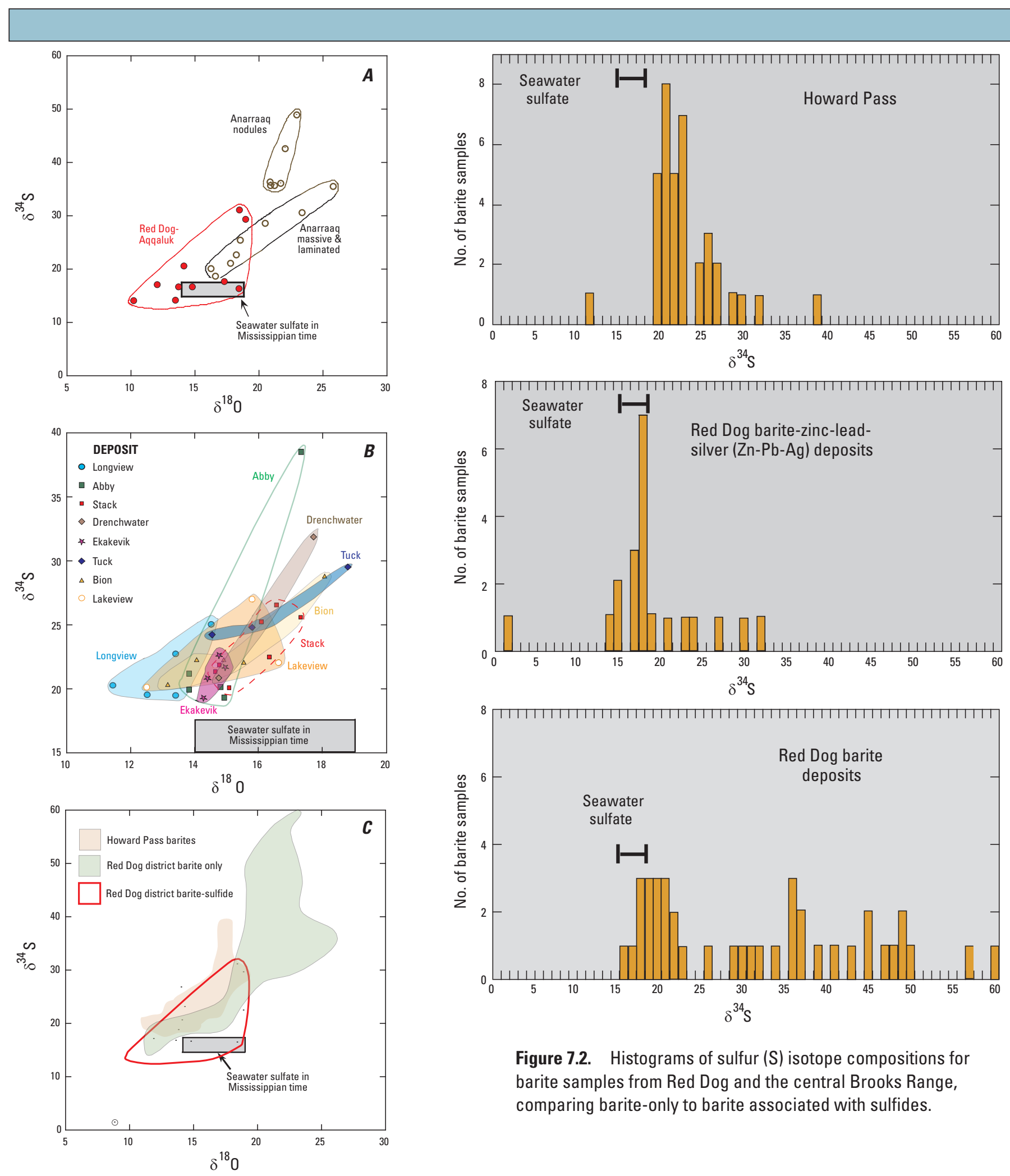

Figure 7.2. Histograms of sulfur (S) isotope compositions for barite samples from Red Dog and the central Brooks Range, comparing barite-only to barite associated with sulfides.

Figure 7.1. Plots of oxygen ( 0 ) versus sulfur (S) isotope compositions for Red Dog and central Brooks Range barite deposits (modified from Johnson and others, 2004). $A$, Barite from a representative lead-zinc-silver deposit (Red DogAqqaluk) and a representative barite-only deposit (Anarraaq) of the Red Dog district. B, Barite from several deposits in the Howard Pass quadrangle, central Brooks Range. C, Comparison of Howard Pass barite deposits and Red Dog district barites (including barite-sulfide deposits at Red Dog-Aqqaluk and barite-only deposits in the district). 


\section{Radiogenic Isotope Studies}

\section{By Robert A. Ayuso}

Radiogenic isotope information (for example, lead and strontium isotopes), can be used to evaluate the contributions of metal sources (ranging from sedimentary to magmatic rocks) and regional fluid flow processes that control metal transport and precipitation. Lead $(\mathrm{Pb})$ and strontium $(\mathrm{Sr})$ isotope data also provide essential insights into the age of mineralization and post-mineralization disturbances.

Lead isotope data were obtained on sulfide minerals from the shale-hosted Zn-Pb-Ag Red Dog deposits (Qanaiyaq, Main, Aqqaluk, and Paalaaq), other shale-hosted deposits near Red Dog, and $\mathrm{Zn}-\mathrm{Pb}-\mathrm{Ag}$ sulfide deposits from the central Brooks Range (fig. 8.1). Galena from the main mineralization stages in the Red Dog deposits and from the Anarraaq and Wulik deposits define a narrow field on standard $\mathrm{Pb}$ isotope diagrams and they display overlapping $\mathrm{Pb}$ isotope compositions (Ayuso and others, 2004). Lead in sulfides of the Red Dog district is less radiogenic (lower values of ${ }^{206} \mathrm{~Pb} /{ }^{204} \mathrm{~Pb}$, ${ }^{207} \mathrm{~Pb} /{ }^{204} \mathrm{~Pb}$ or ${ }^{208} \mathrm{~Pb} /{ }^{204} \mathrm{~Pb}$ ) than the average crustal lead evolution model, consistent with a long history of evolution prior to the Carboniferous. The overall lead isotope homogeneity in the shale-hosted massive sulfide deposits is consistent with a homogeneous regional source, with mixing of lead during the leaching of a thick sedimentary section and fluid transport, and (or) with mixing at the site of deposition. The homogenous compositions indicate that galena deposition resulted from largely similar hydrothermal solutions throughout the western and central Brooks Range, suggesting a flow system that operated at an unusually large scale (many hundreds of kilometers). Younger and genetically unrelated fluids did not significantly disturb the isotopic compositions of galena and sphalerite after the main mineralization event in the Red Dog district.

Strontium isotope data for barite associated with sulfide mineralization (for example, the Red Dog deposits) were compared with data from sulfide-poor barite occurrences, both in the Red Dog district and the central Brooks Range (Ayuso and others, 2004). Fluids with heterogeneous Sr isotope signatures are indicated in figure 8.2. Barite from the Main deposit extends to higher values of ${ }^{87} \mathrm{Sr} /{ }^{86} \mathrm{Sr}$ (0.709034-0.709899) than barite from the Anarraaq deposit $(0.708615-0.709256)$. All barite is more radiogenic than
Carboniferous seawater. Other Mississippian (?) shale-hosted deposits and mineral occurrences containing barite in the Red Dog district and barite from regional occurrences east of Red Dog in the western and central Brooks Range also have heterogeneous ${ }^{87} \mathrm{Sr} /{ }^{86} \mathrm{Sr}$ ratios. The compositions of barite from the central Brooks Range (Howard Pass quadrangle) overlap Carboniferous seawater, at least in part. The variations in $\mathrm{Sr}$ isotope compositions in barite from deposits and occurrences in the Red Dog district and elsewhere in the Brooks Range indicate that no single fluid was responsible for their isotopic signature.

The Sr isotope data do not show compelling differences between textural varieties of barite (coarse-grained versus fine-grained). Higher values of ${ }^{87} \mathrm{Sr} /{ }^{86} \mathrm{Sr}$ in barite from the Red Dog deposits, compared to massive barite at Anarraaq (and other barites that are sulfide-poor) that is not directly associated with massive sulfides, probably reflects the interaction between the former and metal-bearing hydrothermal fluid. Therefore, values of ${ }^{87} \mathrm{Sr} /{ }^{86} \mathrm{Sr}$ in barite may provide a means of distinguishing sulfide-associated barite (high values) from sulfide-poor barite (low values).

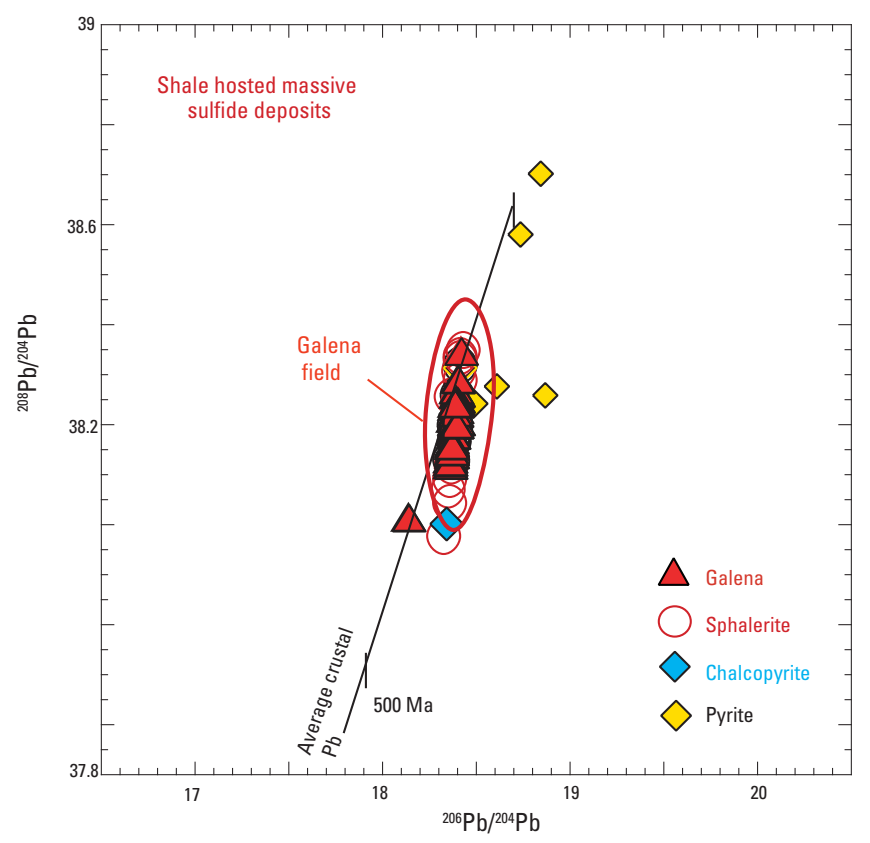

Figure 8.1. Lead $(\mathrm{Pb})$ isotope diagram for sulfides from Red Dog and from the Brooks Range. Average crustal lead evolution curve is from Stacey and Kramers (1975). 


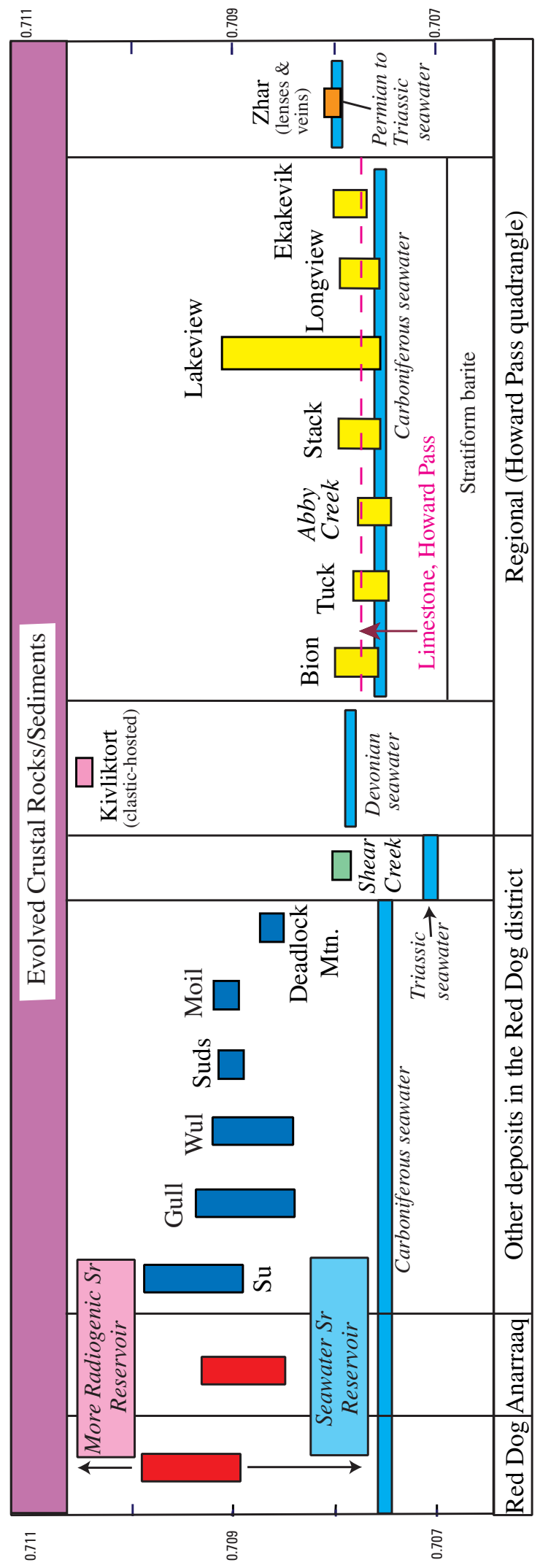

兽

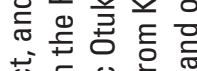

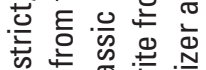

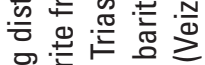

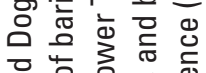
व ब

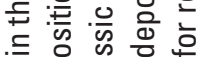

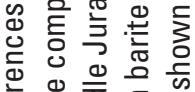
흫 흥 등

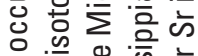

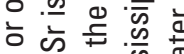

की

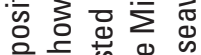

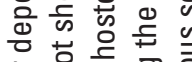
흔흘잉 苍过

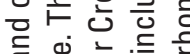
政

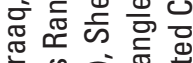

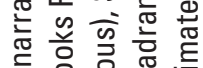

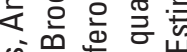

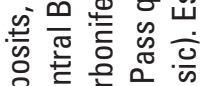

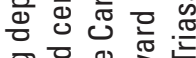

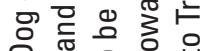

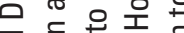

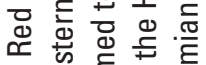
Ф 등 兵号 인.

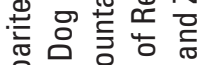

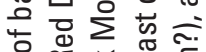
is 送 0 语

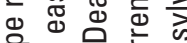
음 ฏ

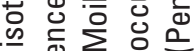

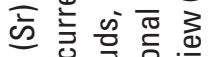

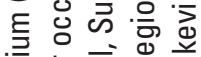
产产㐫 온

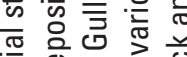

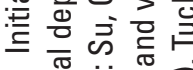

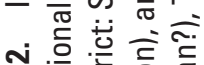

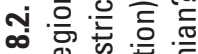

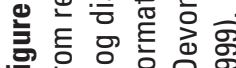




\section{Phosphatic Rocks of the Lisburne Group}

\author{
By Julie A. Dumoulin and John F. Slack
}

Phosphatic rocks are a small but notable part of the Lisburne Group (Permian- Carboniferous), a chiefly carbonate platform succession found in outcrop and in the subsurface throughout northern Alaska. New sedimentologic, paleontologic, and geochemical data better define the geographic and stratigraphic extent of these strata and support tectonic and paleogeographic reconstructions (Dumoulin and others, 2006).

Most Lisburne phosphorites are located in a discontinuous outcrop belt that extends for $265 \mathrm{~km}$ through the westcentral Brooks Range (fig. 1.1), but similar phosphatic rocks also occur in the western Brooks Range and in the subsurface in the Ikpikpuk well north of the Brooks Range. Fossils indicate an age of Late Mississippian (mainly early Chesterian) for Lisburne phosphatic rocks in all of these areas. Phosphatic strata are interbedded with black shale and lime mudstone rich in radiolarians and sponge spicules; they formed largely in poorly oxygenated outer ramp to slope settings.

Where best developed in the central Brooks Range east of the National Petroleum Reserve-Alaska (NPRA), Lisburne phosphorites occur as 2- to 40-cm-thick beds of sand-sized phosphatic grains cemented by carbonate or silica (fig. 9.1). These beds cap sequences of shale and lime mudstone and occur through an interval $\leq 12 \mathrm{~m}$ thick. High gamma ray response through the phosphatic interval indicates strongly condensed facies, likely related to low sediment input and hardground development.

Lisburne phosphorites contain up to 37 wt percent $\mathrm{P}_{2} \mathrm{O}_{5}$, 8.6 wt percent $\mathrm{F}$ (fluorine), and $162 \mathrm{ppm} \mathrm{U}$ (uranium) but their resource potential is limited by relatively low cumulative thickness and discontinuous distribution. Interbedded black shales have up to $20 \mathrm{wt}$ percent TOC (total organic carbon), are potential petroleum source rocks, and typically overlie Lisburne dolostone intervals that contain as much as 13 percent vuggy and intercrystalline porosity. These shales are also locally metalliferous with up to $1,690 \mathrm{ppm}$ chromium (Cr), $1,870 \mathrm{ppm}$ vanadium (V), $461 \mathrm{ppm}$ nickel (Ni), 4,670 ppm zinc $(\mathrm{Zn})$, and $32 \mathrm{ppm}$ silver $(\mathrm{Ag})$. This geochemical signature in the Lisburne phosphatic black shales is similar to that of the Nick Ni-Zn-Mo-PGE deposit in Yukon Territory, Canada (Hulbert and others, 1992), and the Tian'eshan Ni-Mo-PGE deposit in southern China (Coveney and others, 1992).

Paleogeographic reconstructions of northern Alaska imply that Lisburne phosphorites formed in the Ikpikpuk basin and along both sides of the mud-rich Kuna basin (fig. 9.2), which hosts giant massive sulfide and barite deposits of the Red Dog district. Lisburne phosphatic strata are coeval with these deposits and formed as part of a nutrient-rich upwelling regime. The high productivity characteristic of this regime was an important influence on metallogenesis in the Red Dog district, and likely contributed (through nutrification) to the Late Mississippian drowning of carbonate platform environments throughout the southern NPRA. 

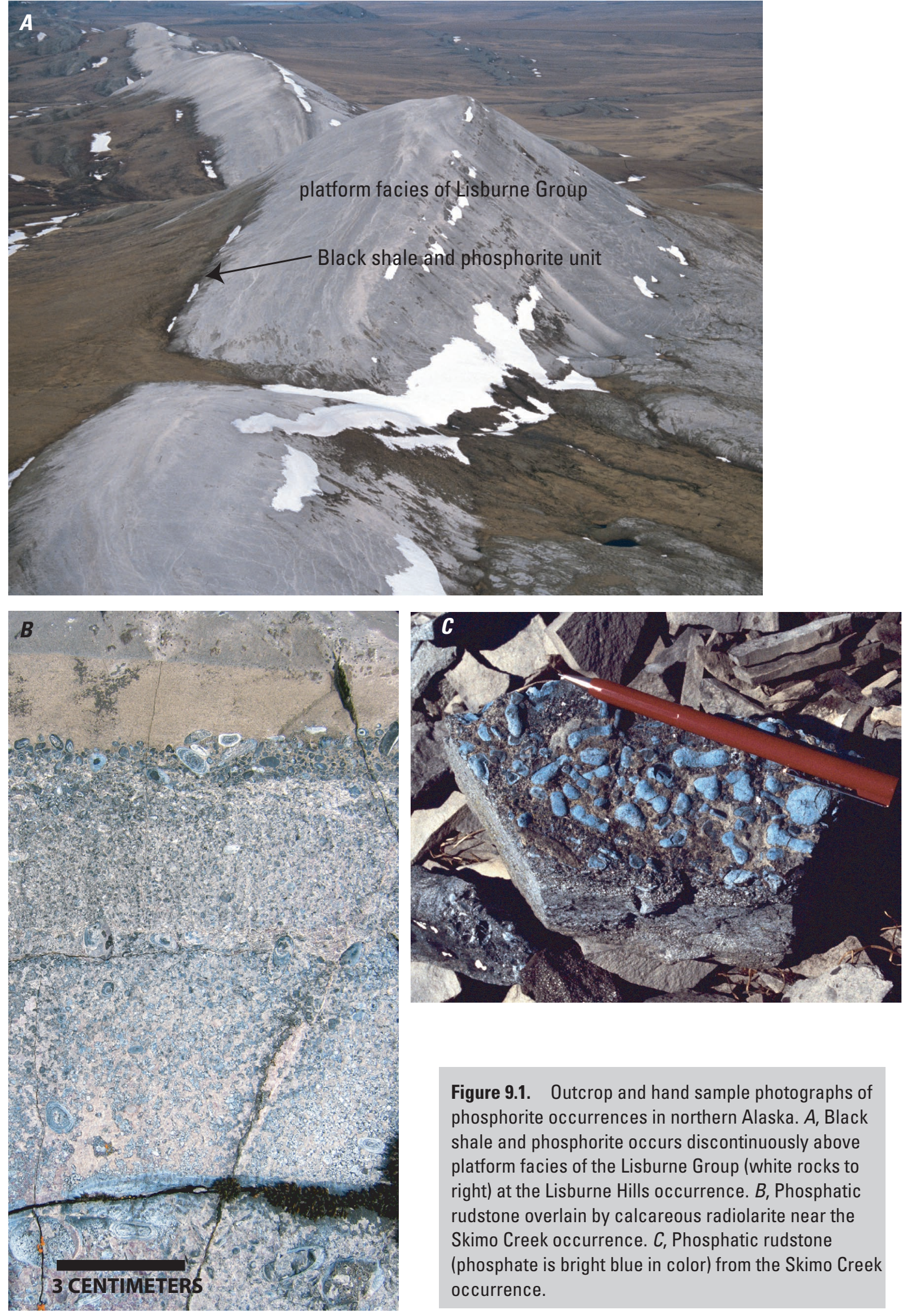

Figure 9.1. Outcrop and hand sample photographs of phosphorite occurrences in northern Alaska. $A$, Black shale and phosphorite occurs discontinuously above platform facies of the Lisburne Group (white rocks to right) at the Lisburne Hills occurrence. $B$, Phosphatic rudstone overlain by calcareous radiolarite near the Skimo Creek occurrence. $C$, Phosphatic rudstone (phosphate is bright blue in color) from the Skimo Creek occurrence. 


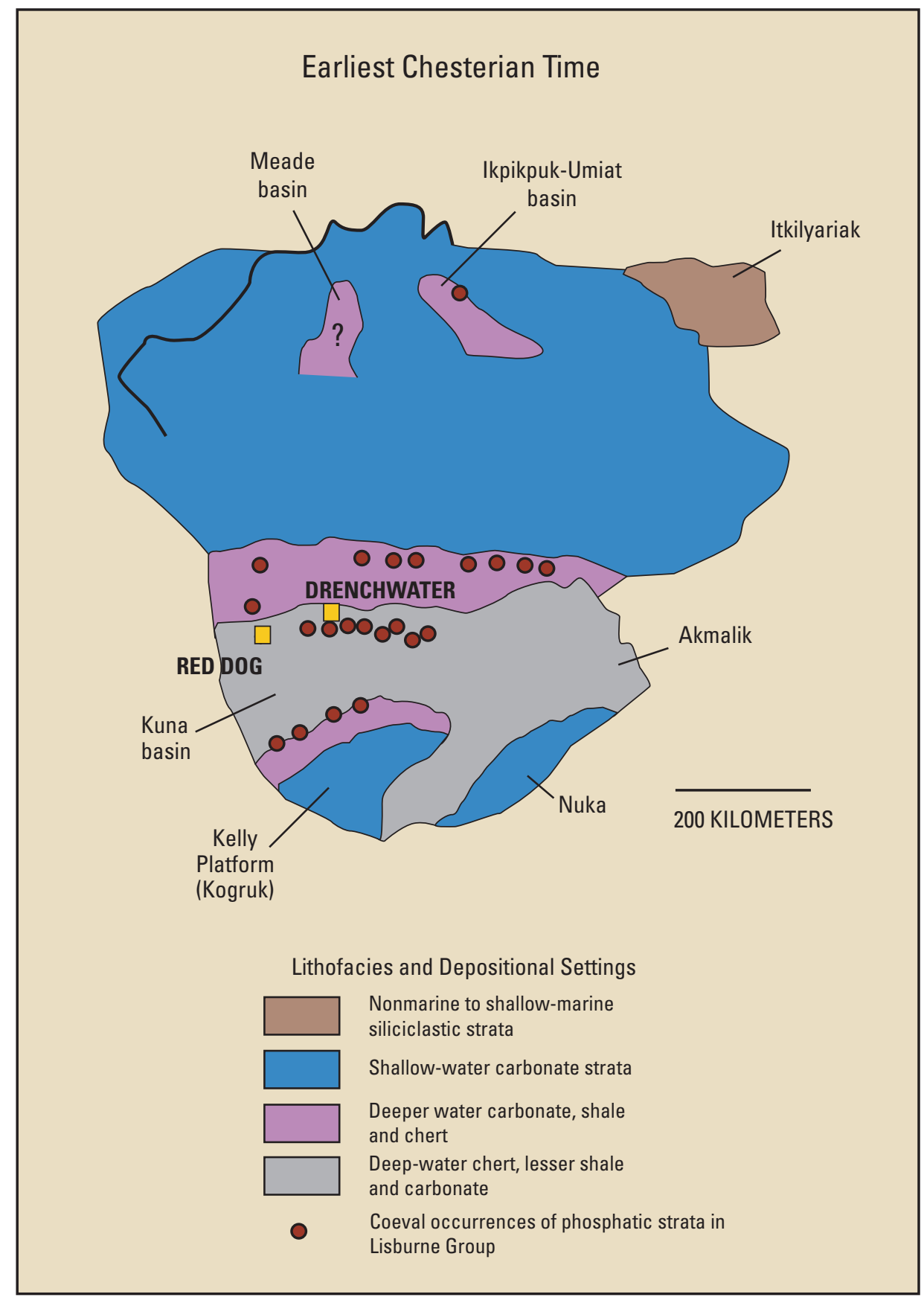

Figure 9.2. Palinspastic restoration of northern Alaska showing location of phosphatic strata surrounding the Kuna basin. 


\section{Metalliferous Tasmanite and Oil Shale}

\author{
By Erin E. Marsh, Julie A. Dumoulin, Karen D. Kelley, \\ and John F. Slack
}

Occurrences of oil shale in the Brooks Range were first reported in the literature in the late 1800s. The early explorers commented on the use of this material by natives for fuel. Outcroppings were first described by Smith and Mertie (1930) from exposures along the Kiligwa River. In the 1950s and 1960s, Irv Tailleur (USGS) visited and resampled many of the sites during studies in the National Petroleum Reserve-Alaska (NPRA). Tourtelot and Tailleur (1966) reported exceptionally large oil yields of 146 and 144 gallons per ton from two samples of organic-rich shale. Other samples yielded about 25 to 50 gallons of oil per ton. In addition, semiquantitative spectrographic analyses of some samples indicated that vanadium (V), zinc ( $\mathrm{Zn})$, and molybdenum (Mo), as well as gold (Au), silver $(\mathrm{Ag})$, arsenic (As), nickel $(\mathrm{Ni})$, and mercury $(\mathrm{Hg})$ were present in high concentrations compared to other oil shales.

In order to put the oil shales into a modern stratigraphic and structural context and to evaluate earlier reports of high metal contents, five of the oil shale localities in the Howard Pass quadrangle were visited (fig. 10.1). Samples were collected for petrography and selected samples were submitted for geochemical analyses using modern techniques.

Two types of oil shale in northern Alaska (fig. 10.2) are tasmanite (made up of algal material) and black oil shale (rich in various forms of organic matter). The fossil of unicellular marine algae, Tasmanites, has been observed interspersed in basinal sediments in many localities worldwide. In a few locations, deposition of massive concentrations of these organisms has formed an oil shale consisting almost entirely of telalginite derived from Tasmanites (Cook and Sherwood, 1991).

Although noted in several locations (Sweden, Sahara, Alaska, Brazil), the tasmanite deposits in Tasmania are the most well-known. In Alaska, tasmanite occurs not only in the Brooks Range but also in the Yukon Flats area, although the characteristics and extent of these oil shale lenses have yet to be determined (Lillis and Stanley, 2005).

The tasmanite in northern Alaska is pale yellowish-brown in outcrop, and on freshly broken, unweathered surfaces has a dark reddish-brown resinous luster and a woody appearance (fig. $10.2 B, C$ ). In thin sections it consists of a mass of flattened Tasmanites spores that contain minor barite. The tasmanite is intercalated with white layers that consist of silicafilled (and partly replaced) flattened and unflattened Tasmanites spores. The tasmanite typically includes pyrite nodules (as much as $0.5 \mathrm{~cm}$ in diameter) that are sporadically distributed. The pyrite appears to have formed on or near the surface as the spores were deposited. The tasmanite beds are associated with radiolarian chert; at one location, tasmanite overlies chert of Late Mississippian-Permian age. Some tasmanite samples are so oil-rich that they can burn (fig. 10.2D).

Black oil shale in outcrop has a low density; therefore, it is very lightweight. In thin section it consists of orange-red organic material with disseminated quartz silt. Pyrite typically occurs as discontinuous thin (as much as $3 \mathrm{~cm}$ thick) lenses intergrown with gray shale (fig10.2A). Similar to tasmanite, the oil shales are associated with radiolarian chert of unknown age.

The pyrite separates are generally low in most metals; exceptions include high concentrations of As (2,460 ppm) and $\mathrm{Ni}(290 \mathrm{ppm})$ in pyrite from tasmanite. High metal concentrations in whole-rock samples of oil shale reported previously (Tourtelot and Tailleur, 1966) were largely confirmed by our recent data, with a few exceptions. Our samples collected in 2005 contain high $\mathrm{Cu}$ (copper; as much as 800 ppm), $\mathrm{Hg}$ (2,410 ppb), Mo (340 ppm), Ni (410 ppm), Se (selenium; $100 \mathrm{ppm})$, and V (6,760 ppm). High concentrations of Au and $\mathrm{Zn}$ reported in previous studies (maximum values of $150 \mathrm{ppb}$ and 7,000 ppm, respectively) were not observed in either the tasmanite or black shale samples.

A comparison of Alaskan oil shale samples with other organic-rich and oil shale localities (table 10.1) suggests some similarities. Some organic-rich (12 to $25 \mathrm{wt}$ percent organic carbon) portions of the Devonian-Mississippian New Albany Shale in southern Indiana are enriched in cadmium (Cd; 130 ppm), copper (Cu; 177 ppm), lead ( $\mathrm{Pb} ; 795$ ppm), molybdenum (Mo; 562 ppm), nickel (Ni; 498 ppm), vanadium (V; 3,200 ppm), and zinc (Zn; 9,725 ppm) (Ripley and others, 1990); and the Pennsylvanian-age Mecca Quarry Shale and Logan Quarry Shale from Illinois and Indiana, respectively, contain enriched concentrations of Mo (1,600 ppm), Se (400 ppm), U (240 ppm), V (10,100 ppm), and Zn (14,300 ppm) (Coveney and Martin, 1983). Known metalliferous oil shales include Devonian kerogenous marine strata in central Nevada, which contain anomalously high concentrations of Mo (960 ppm), Se (200 ppm), V (3,200 ppm), and Zn (18,000 ppm) (Desborough and others, 1979). 


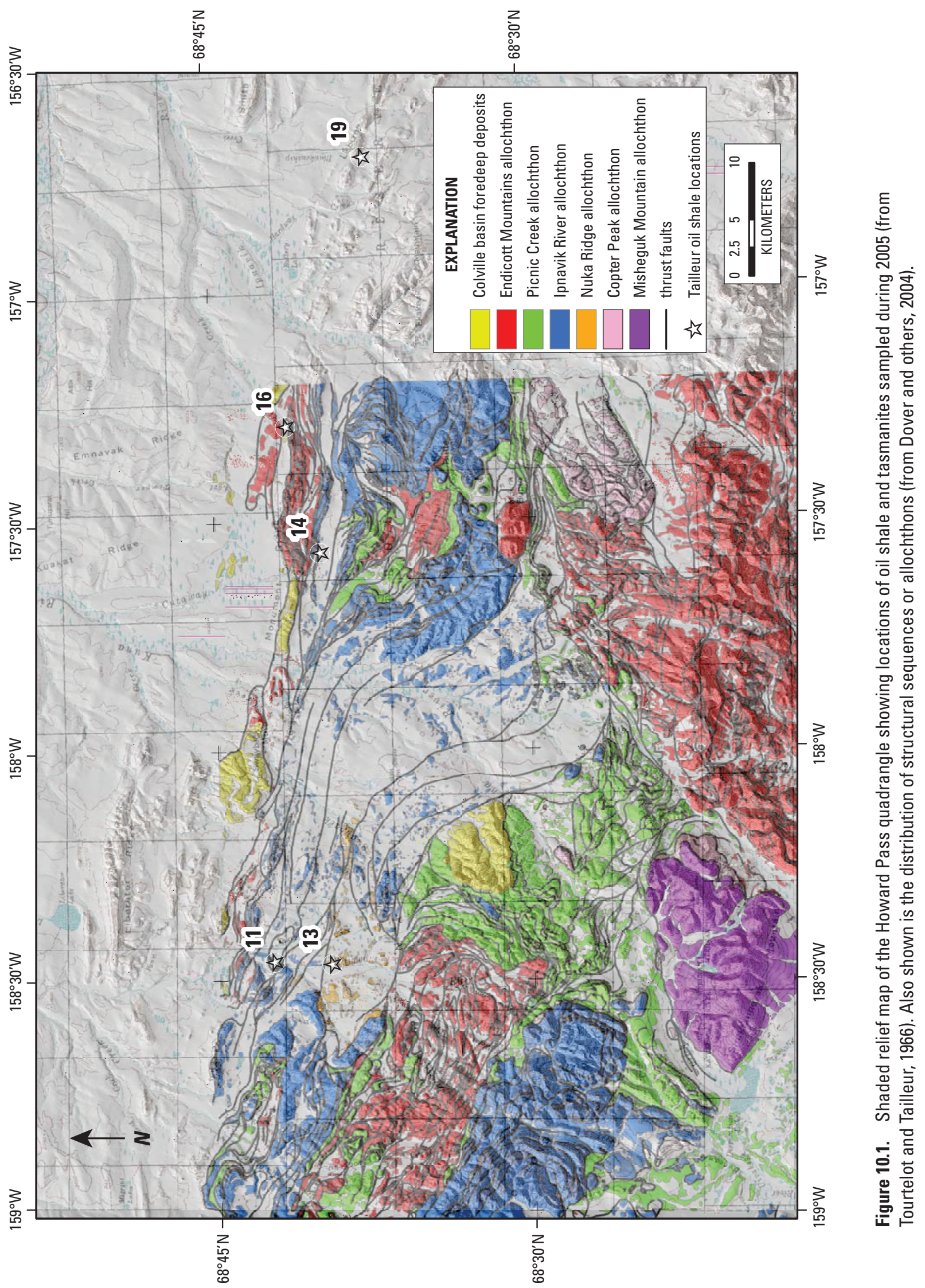



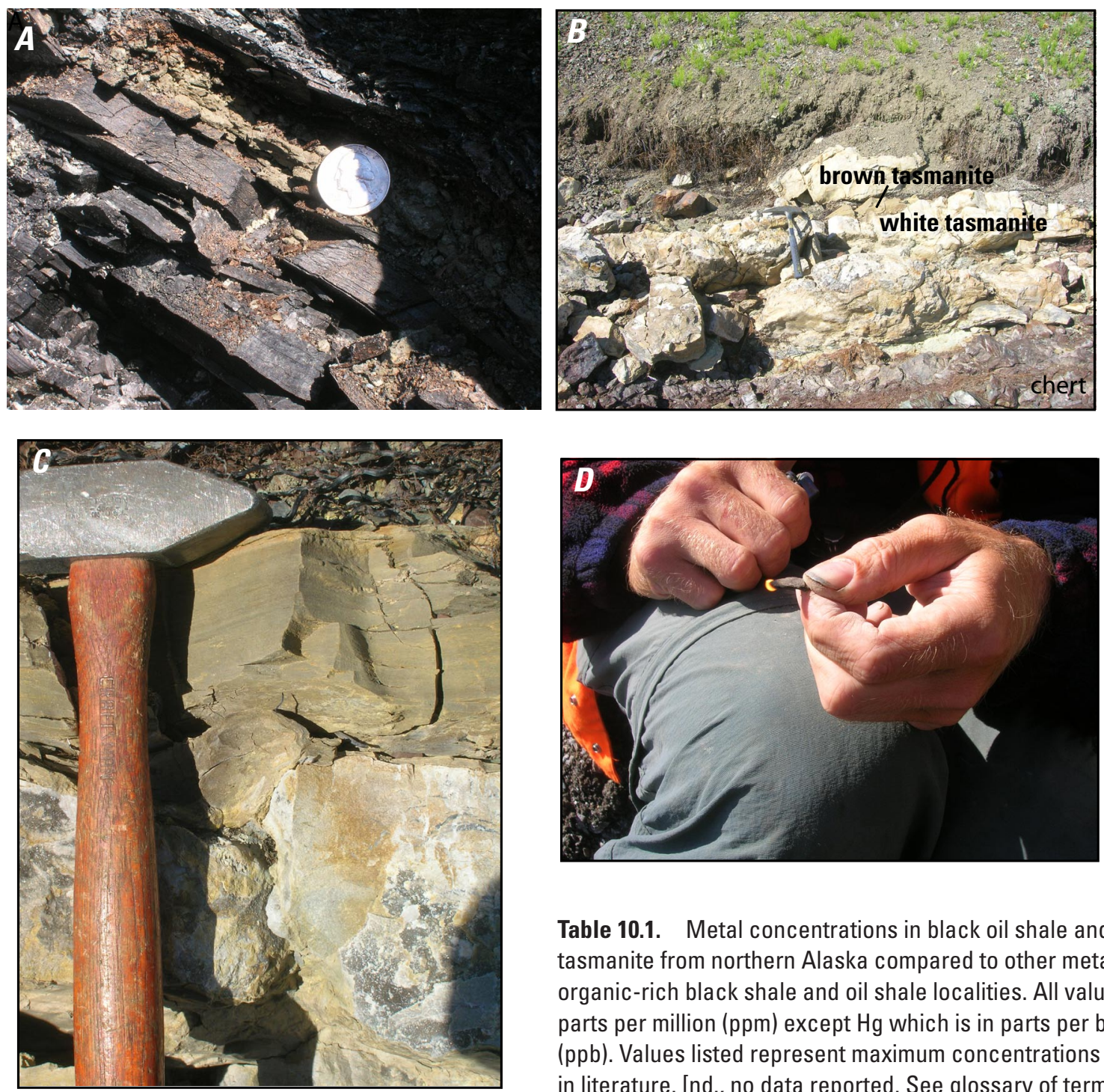

Table 10.1. Metal concentrations in black oil shale and tasmanite from northern Alaska compared to other metalliferous organic-rich black shale and oil shale localities. All values in parts per million (ppm) except $\mathrm{Hg}$ which is in parts per billion (ppb). Values listed represent maximum concentrations reported in literature. [nd., no data reported. See glossary of terms for names of elements (symbols only shown in table)]

Figure 10.2. Outcrop photographs of oil shale occurrences. $A$, Oil shale site no. 11: pyrite lens in black shale. $B$, Tasmanite site no. 14: tasmanite contains pyrite nodules. $C$, Tasmanite site no. 14: tasmanite (brown material at top) is intercalated with white layers that consist of silica in tasmanite. Pyrite nodules occur in the brown tasmanite. $D$, Tasmanite is so oil-rich it can burn. For site locations, see figure 10.1.

\begin{tabular}{lcccc}
\hline Elements & $\begin{array}{c}\text { Northern } \\
\text { Alaska }\end{array}$ & $\begin{array}{c}\text { New Albany } \\
\text { Shale }\end{array}$ & $\begin{array}{c}\text { Mecca Quarry/ } \\
\text { Logan Quarry }\end{array}$ & Nevada \\
\hline $\mathrm{Cd}$ & 90 & 130 & nd & nd \\
$\mathrm{Cu}$ & 800 & 177 & 500 & nd \\
$\mathrm{Hg}$ & 2,410 & $\mathrm{nd}$ & nd & nd \\
$\mathrm{Ni}$ & 410 & 498 & nd & nd \\
$\mathrm{Mo}$ & 340 & 562 & 1,600 & 960 \\
$\mathrm{~Pb}$ & 60 & 795 & 500 & nd \\
$\mathrm{Se}$ & 100 & nd & 400 & 200 \\
$\mathrm{U}$ & 70 & nd & 240 & nd \\
$\mathrm{V}$ & 6,760 & 3,200 & 10,100 & 3,200 \\
$\mathrm{Zn}$ & 940 & 9,725 & 14,300 & 18,000 \\
\hline
\end{tabular}




\section{Preliminary Retrodeformable Regional Cross Section, Western Brooks Range}

\author{
By Thomas E. Moore and Christopher J. Potter
}

The western Brooks Range is a northwest-directed foreland fold-and-thrust belt. The $\mathrm{Zn}-\mathrm{Pb}-\mathrm{Ag}$ mineral deposits are located in Mississippian basinal rocks that were displaced by large-magnitude thrust faults into allochthonous structural positions in the Cretaceous and Tertiary (Mull, 1982; Moore and others, 1986; Mayfield and others, 1988). A preliminary retrodeformational cross section from the Kugururok River in the axial part of the Brooks Range to Tupikchak Creek in the deformed part of its foreland basin (fig. 11.1) has been constructed (Moore and Potter, in press). This cross section provides a better understanding of the geologic context of the deposits at the time of ore formation, an estimate of the amount of crustal shortening that has taken place in the Brooks Range, and an opportunity to test the viability of deformational models that call for multiple episodes of deformation in the Brooks Range as recently proposed by Moore and others (2004). It also provides a mechanism for reconstructing the depositional extent of the Mississippian basin that hosted the Red Dog massive sulfide deposits and for determining the nature of aquifers that served as conduits for hydrothermal fluids.

The top of the cross section (fig. 11.2) depicts the exposed geology as presently known along the northwest trending line of section. Rocks in the section are interpreted to compose parts of a south-facing Mississippian to Jurassic passive margin that were imbricated by north-directed thrusting during the Brookian orogeny (Moore and others, 1994). The structurally lowest and originally the most proximal part of the passive margin succession is the autochthon, which underlies the North Slope and is interpreted as undeformed and gently southward dipping at depths of more than $9 \mathrm{~km}$ in the cross section. The 2- to 5-km-thick Endicott Mountains allochthon, which is divided into Wolverine Creek, Red Dog, and Key Creek plates, overlies the autochthon on a regional flat thrust developed in Jurassic and Lower Cretaceous strata of the autochthon. The most distal parts of the passive margin succession are represented by the Kelly River allochthon, a tabular structural unit exposed in klippen near the crest of the Brooks Range, and the Ipnavik River allochthon, which is present only in the southern part of the cross section. These allochthons were also emplaced on flat thrusts developed in Jurassic strata early during the period of thrusting but have been further deformed by younger faults and folds that developed after the allochthons were emplaced. The structurally highest rocks of the Brooks Range orogen are klippen of igneous rocks that represent the uppermost plate of the orogen, beneath which the passive margin was thrust. The Picnic Creek allochthon of Mayfield and others (1988) is not present in our line of section and here is regarded to compose part of the Key Creek plate of the Endicott Mountains allochthon because (1) it is laterally discontinuous in the western Brooks Range, and (2) its lithostratigraphy and environments of deposition are similar to those in the Key Creek plate (Dumoulin and others, 2004).

Foreland basin deposits are the deposits that were shed from the developing mountain belt and are thickest in the northern part of the cross section. There, they are mainly Aptian to Cenomanian and display relatively simple stratigraphy where deposited on the autochthon. Farther south where deposited on allochthonous rocks, foreland basin deposits have less certain stratigraphy and age relations because of their involvement in complex folds and thrusts associated with emplacement of the allochthons. In these areas, the foreland basin deposits are latest Jurassic and Neocomian.

Internal thrusting within stratigraphic sequences of the allochthons resulted in structural repetition of strata between less deformed overlying and underlying strata (duplexes). This type of deformation notably affected the host strata for the Red Dog mineral deposits, which are located in the Red Dog plate of the Endicott Mountains allochthon.

The thrusts at the base of the allochthons are interpreted to have originally formed as flat bedding plane thrusts in Devonian strata that cut upward to the north, resulting in emplacement of the allochthons onto Jurassic and Lower Cretaceous strata on adjacent parts of the passive margin. Thrusts cut upward into overlying strata progressively through time, imbricating units within the allochthons, including the duplexes that host the Red Dog mineral deposit. Worldwide, flat thrusts and duplexes with large amounts of displacement and allochthons with thin stratigraphic thicknesses such as those seen in the western Brooks Range are ascribed to thinskinned style thrusting.

Moore and others (2004) proposed that the latest Jurassic and Early Cretaceous thin-skinned thrust belt was redeformed by a completely separate system of thrusts active in the Early Tertiary. This younger system of thrusts deformed a thick structural section consisting of the earlier formed stack of allochthons, duplexes, and accompanying foreland basin sediments from the earlier deformation. The younger thrusts truncated the earlier generation of thrusts and caused significant uplift in the Brooks Range, but produced much less displacement than that seen in the latest Jurassic and Early Cretaceous deformational belt. Nonetheless, the later generation of thrusts produced some of the most conspicuous folds and faults in the young, thick, and previously undeformed parts of the foreland 
basin. The Early Tertiary deformation produced wide-spaced detachment folds in the foothills of the northern Brooks Range and, farther south, truncated the Cretaceous thrusts on broadly spaced north-directed reverse faults. In addition to these types of structures, normal faults were observed along which higher allochthons in the orogen were dropped down to the southeast and juxtaposed against the Endicott Mountains allochthon. Such normal faults are present in the southern part of the cross section. The age and cause of the normal faulting are uncertain but the faults are interpreted here to be the northernmost faults of the regionally extensive belt of middle Cretaceous down-to-the-south extensional deformation in the southern Brooks Range (see, for example, Miller and Hudson, 1991). Despite differences in their depth of burial at the time of the various deformations, the contractional deformations utilized the Jurassic and Lower Cretaceous Kingak Shale at the top of the autochthon as their primary detachment horizon under the northern Brooks Range.

The cross section presented in figure 11.2 is a regional section designed to be kinematically retrodeformable, such that faults and folds can be sequentially restored to plausible pre-deformational stratigraphic locations without significant volume changes, crossing faults or other geometric impossibilities. This restoration must be done successively for each of the three deformations. A simple cut-and-paste balancing of line lengths and areas of the section allows calculations of the approximate amount and percent shortening on a regional basis. However, the section is not rigorously balanced and errors of as much as 20 percent are possible. Duplexes of stratigraphic units (for example, Endicott Group, Lisburne Group) within some allochthons are illustrated with form lines, but no attempt has been made to retrodeform these structures. The qualitative section is useful for testing whether the structural hypothesis is plausible and suitable for a more detailed analysis and modeling. For this reason, the model is regarded as approximate and preliminary.
Retrodeformation of the cross section indicates that a multi-deformational structural history consisting of (1) thinskinned deformation in the early Cretaceous, (2) extensional faulting in the mid-Cretaceous, and (3) thin- to thick-skinned deformation in the Early Tertiary is a viable model of deformation for western Brooks Range structures. This qualitative restoration suggests shortening on the Early Tertiary structures totals about $35 \mathrm{~km}$ and about 30 percent shortening over the length of the cross section. Shortening during the latest Jurassic and Early Cretaceous deformational event is significantly higher, representing about $200 \mathrm{~km}$ of shortening. Estimates of the total shortening in the Brooks Range range from 500 to $800 \mathrm{~km}$ (Oldow and others, 1987; Mayfield and others, 1988), but some workers have argued for much lower amounts of total shortening (see, for example, Kelley and Brosgé, 1995). Our estimate of shortening in this paper, however, is only for the northern Brooks Range and therefore represents only part of the total shortening for the Brooks Range. Restoration of the Red Dog plate indicates that the Red Dog mineral deposits probably formed stratigraphically above the Endicott Group but the precise location to which the host strata should be restored is poorly constrained because of the complexities of restoring the duplexes, especially those that contain the Red Dog massive sulfide deposits.

Key assumptions involved in the construction of the section include (1) the autochthon is undeformed and (2) the Wolverine Creek plate of the Endicott Mountains allochthon is thick and extensive at a depth of about $4-10 \mathrm{~km}$ in the cross section. This cross section interpretation also awaits analysis of thermal maturity and thermochronologic data currently in progress. Additional information bearing on these and other assumptions could support alternative structural models, and are the focus of future studies. 


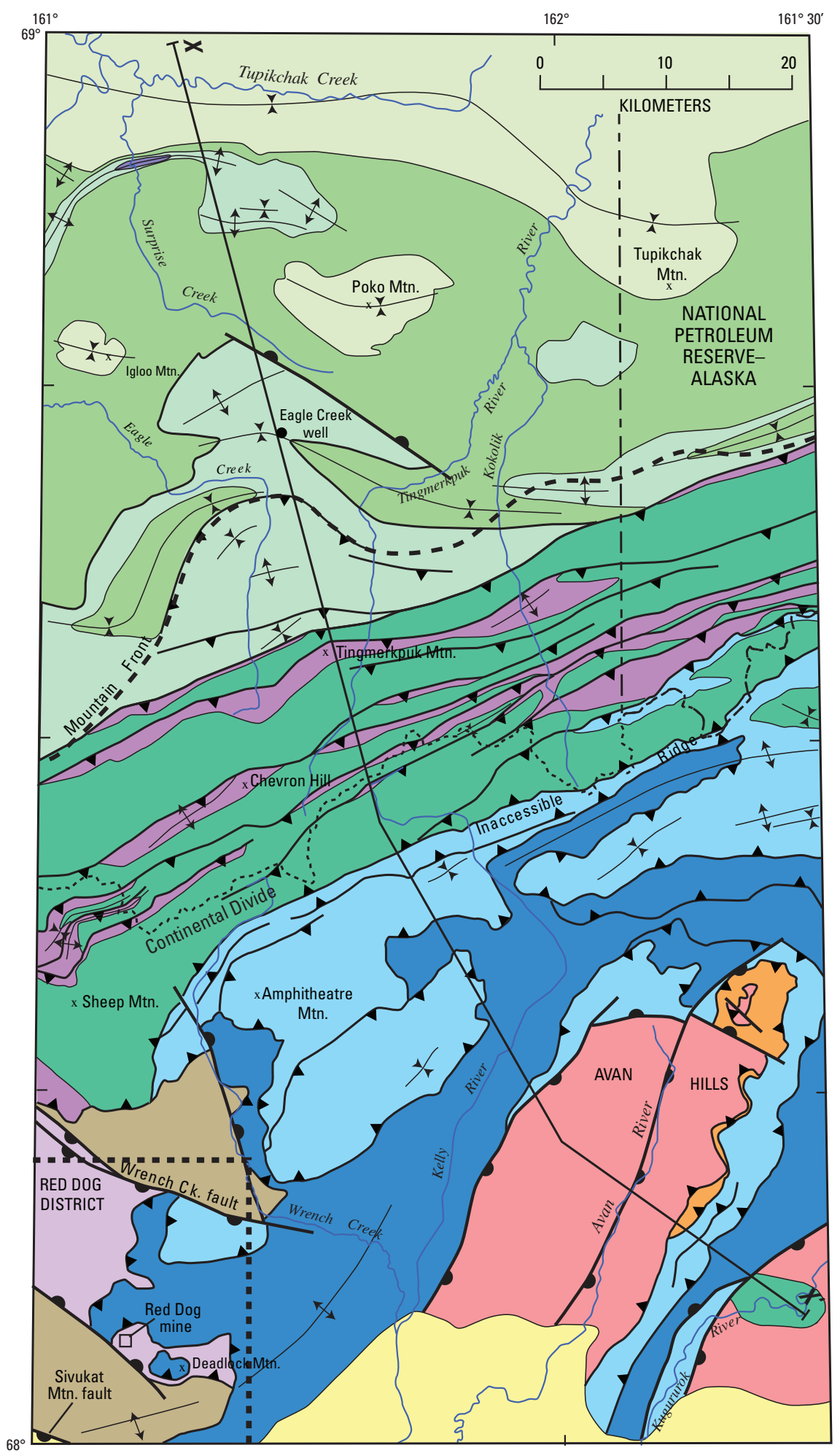

\section{EXPLANATION}

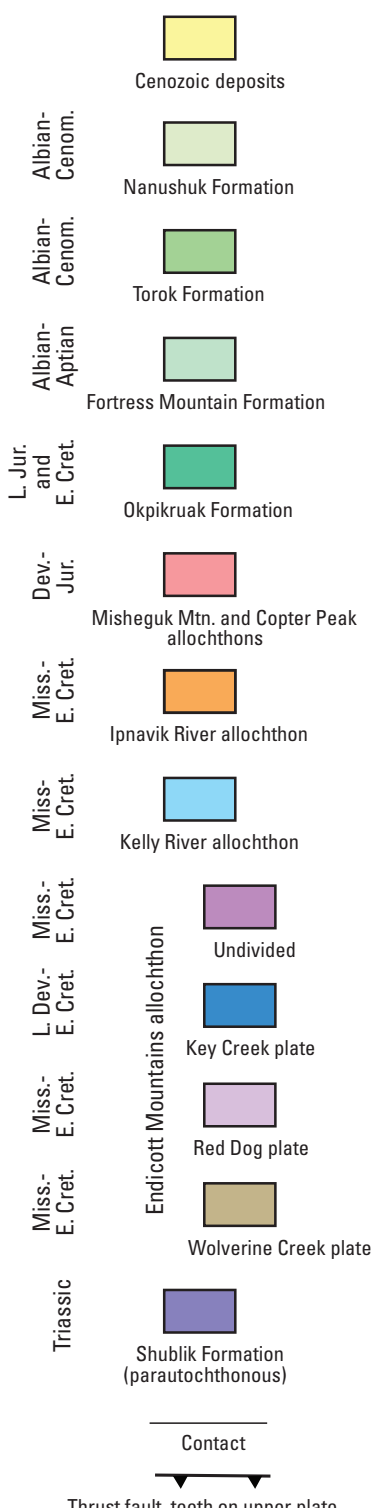

Thrust fault, teeth on upper plate

Normal fault, teeth on hanging wall

$$
\begin{aligned}
& \frac{\hat{\uparrow}}{\text { Anticline }} \\
& \frac{\mathbf{y}}{\text { Syncline }} \\
& \text { - - - - }
\end{aligned}
$$

National Petroleum Reserve boundary

- $=$ -

Red Dog district boundary

Figure 11.1. Map showing major structures and structural units and location of cross section. Okpikruak Formation not shown south of the Continental Divide, except near the Kugururok River. Picnic Creek allochthon included with Endicott Mountains allochthon and Nuka Ridge allochthon included with Ipnavik River allochthon. Sources of data: Curtis and others (1984, 1990), Ellersieck and others (1990), De Vera and others (2004), and C.G. Mull (written commun., 2006). Cross section X-X' shown on figure 11.2. 

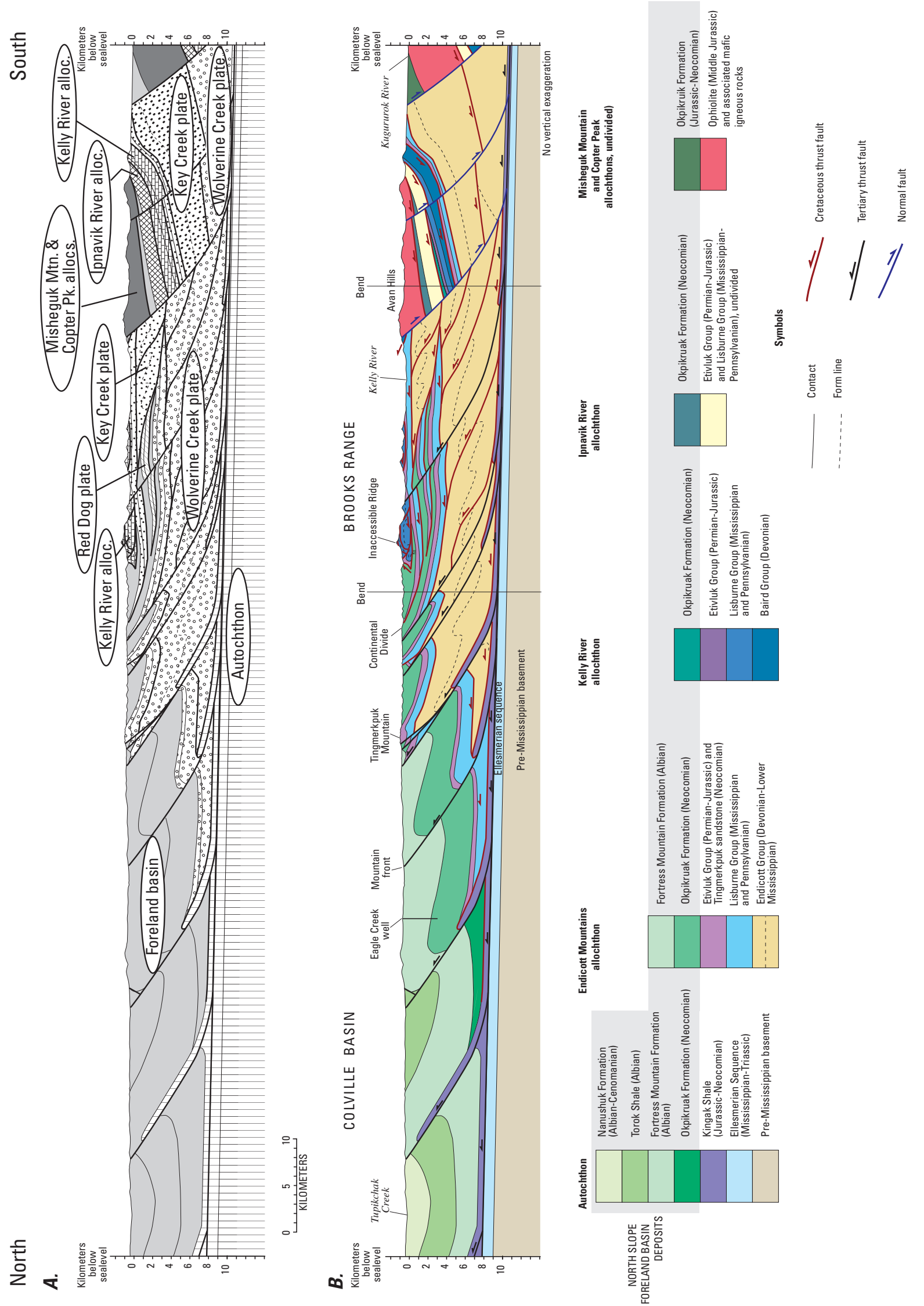

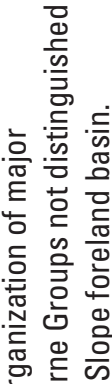

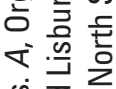

si

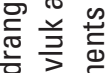

豞豈

б.

高壱苍

䓂. 응 윰

$\sum \frac{1}{2}$

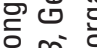

ه

을 음

등

芌.

这焉

言 흥

क्ष

$\sum$.

范 $\frac{\bar{c}}{\mathrm{~N}}$

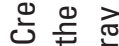

要范宁

过 这

흠 흠 혼

兽员

㐫 元

릴

흔 贾

空

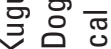

등 웅

立

希

흡 음

प्ष

क 긍 등

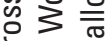

U

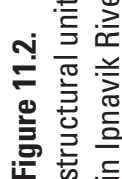




\section{Geologic Rationale for Extensional Basin Framework During Red Dog Mineralization}

\author{
By Christopher J. Potter and Julie A. Dumoulin
}

In order to understand the ore forming processes for a mineral deposit, it is necessary to determine the geologic framework that existed when the ore deposit formed. In the case of the Red Dog massive sulfide district in the western Brooks Range, Alaska, where the mineral deposits formed in Mississippian-age deep-water sediments, geologic and isotopic studies strongly indicate that mineralization occurred shortly after these sediments were deposited on the ocean floor. To develop physical and numeric models for the formation of these ores, scientists need to infer: (1) the chemical processes responsible for the ore formation; (2) the physical conditions (pressure, temperature) under which such processes operated; and (3) the geologic framework (configuration of the significant strata) at the time of ore formation. This chapter addresses the geologic framework of the ore-forming process, and specifically how this framework is incorporated into models aimed at simulation of ore-forming processes.

Reactive transport hydrologic models for mineralization in the Red Dog massive sulfide district (Schardt and others, in press) are based on an interpreted geologic framework (fig. 12.1). This framework is necessarily simplified, relative to the complex geologic situation that undoubtedly existed during ore formation. We use a simplified framework for two reasons: (1) the computer-based numerical model cannot efficiently handle a geologic configuration that is too complex, so there is a trade-off between geologic complexity and computing speed; and (2) the younger geologic history of the ore district (after the formation of the ore in Mississippian time) is complex, and it is difficult to "see through" the complex younger faulting to get at the true original configuration.

Figure 12.2 shows a present-day regional cross section through the Red Dog area, from De Vera and others (2004). The prominent curved thrust faults on this illustration formed in Early Cretaceous time, with additional faulting likely in early Tertiary time. These structures produced intense lateral shortening and vertical thickening of the original south-facing ocean margin that underlay northern Alaska. (In aggregate, the faults in figure 12.2 have produced over $200 \mathrm{~km}$ of northwest-southeast shortening; Moore and Potter, this volume, section 11). As a result, the sedimentary rocks that represent the deep ocean basin in which the Red Dog deposits formed have been severely modified since the ore-forming event.

The Mississippian Kuna Formation hosts the Red Dog and related ore deposits. This formation consists of black shale, chert, limestone and other minor components that accumulated in a deep-water setting (Dumoulin and others, 2004). The Kuna basin, in which these rocks accumulated, is estimated to have been anywhere from 0.1 to $2.5 \mathrm{~km}$ deep and at least $300 \mathrm{~km}$ long (Dumoulin and others, 2004; Young, 2004). The varied sedimentary facies and locally abrupt thickness changes in the Kuna basin strongly suggest that this basin was the site of active faulting. Submarine block faulting was likely a factor in producing the complex variations in water depth and sediment thickness (Dumoulin and others, 2004; Kelley, Dumoulin, and Jennings, 2004).

Regional considerations are consistent with an extensional tectonic setting in the Kuna basin. The Hanna trough, currently present beneath the Chukchi Sea north-northwest of Red Dog, is a north-northwest trending feature that records Devonian through early Mississippian extension. The Ikpikpuk-Umiat basin in the subsurface of the North Slope, north of the Brooks Range, appears to record extension at that time as well (Bird, 2001). Seismic lines on the North Slope, eastnortheast of Red Dog and intermediate in position between these two basins (fig. 12.3) also record extensional deformation at this time. It is not unreasonable to conclude that the Kuna Basin would have undergone extensional deformation as well.

Figure 12.1, a diagram of a basin configuration that was used in numerical modeling of the Anarraaq deposit near Red Dog (Schardt and others, in press), represents a very small extensional basin that would have been a component of this much larger, regional extensional province. In this model, this subbasin is considered to be of the appropriate scale to model the Anarraaq massive sulfide deposit. The basis of the cross section is the variation in thicknesses of the stratigraphic units of the Kuna Formation in the vicinity of the deposit. These thicknesses are accommodated in a structural style called an asymmetric graben, which is a basin that has been downdropped between two normal faults that have significantly different amounts of offset. This results in a strongly asymmetric, tilted basin that is a common style in the North Sea. The modeled basin would be considered to be just one of a large number of such subbasins within the regional Kuna basin. 


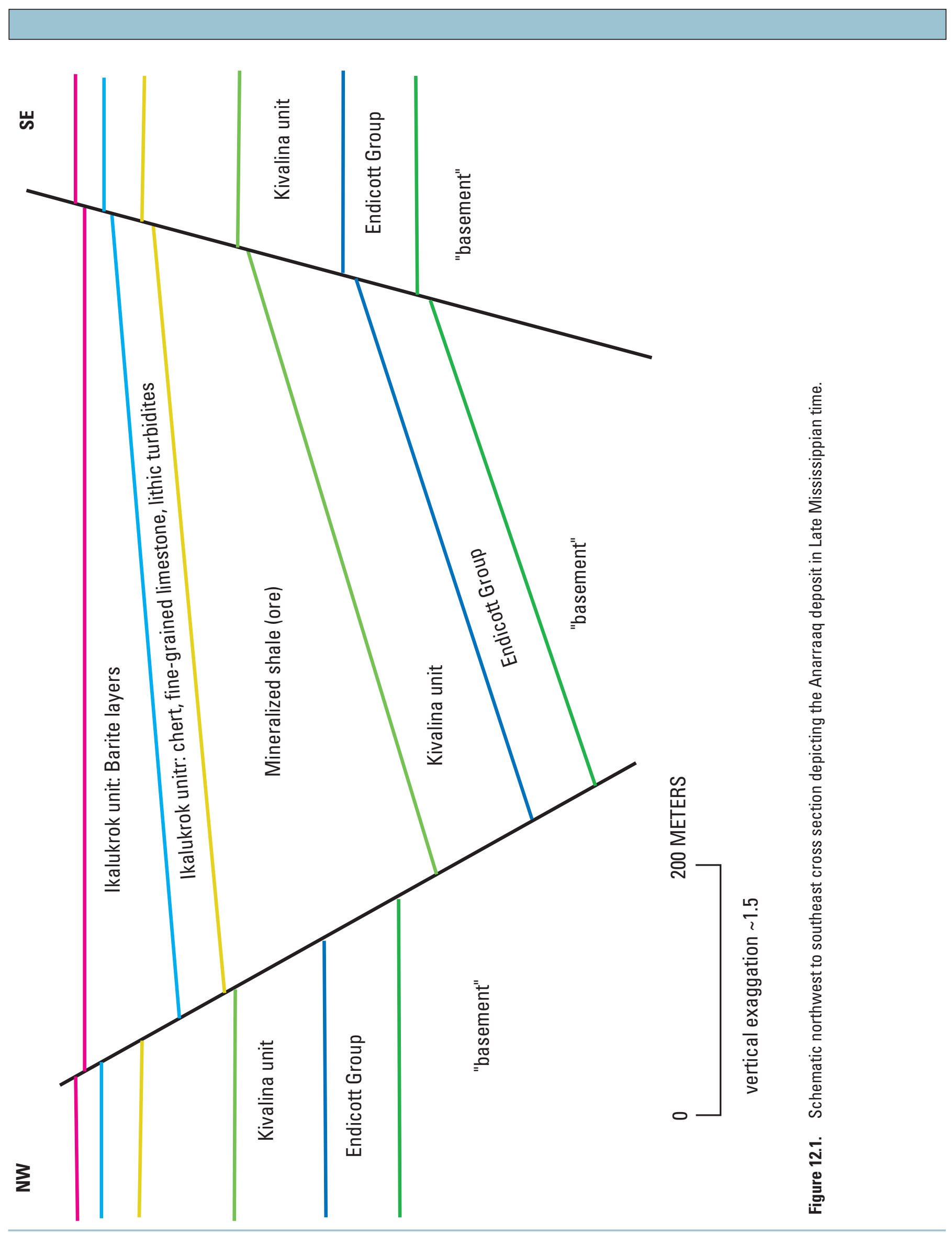




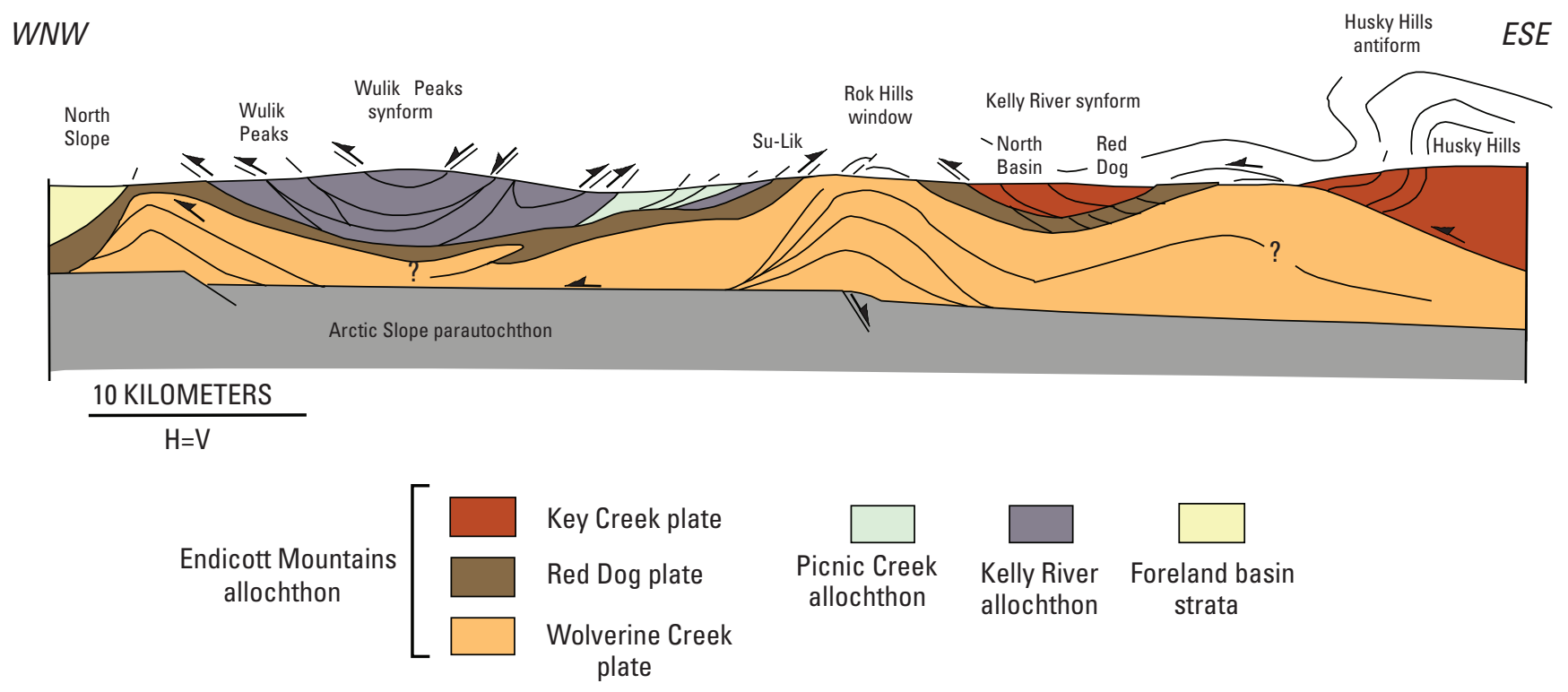

Figure 12.2. Geologic cross section through the Red Dog district (from DeVera and others, 2004). 


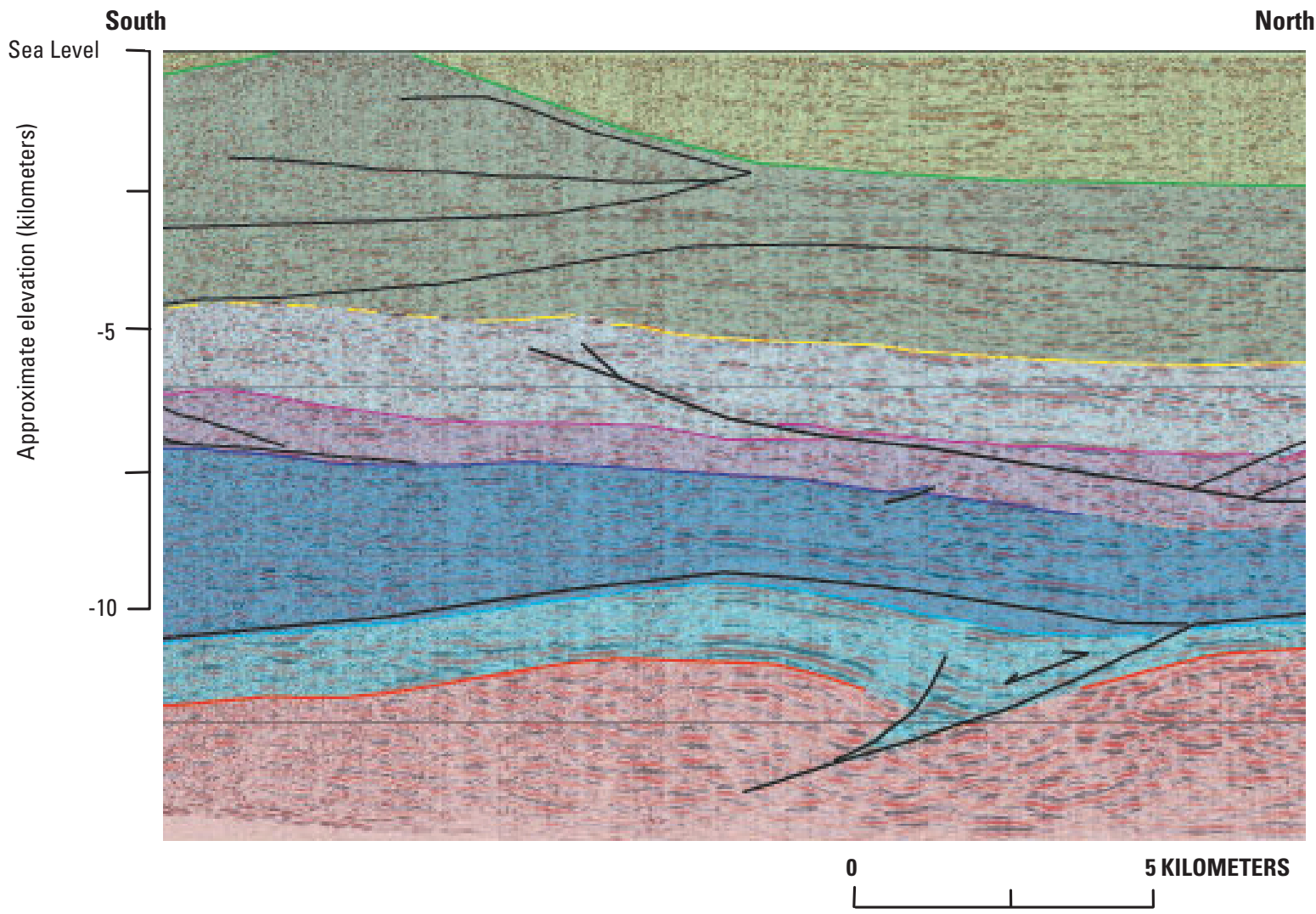

EXPLANATION

Nanushuk Formation

(Albian-Cenomanian)

Torok and Fortress Mountain Formations (Aptian-Albian)

Kingak Shale

(Jurassic-Neocomian)

Sadlerochit Group (Permian-

Triassic) \& Shublik Formation (Triassic)

Lisburne Group (Mississippian-Permian)

Endicott Group (Devonian- Mississippian)

Pre-Mississippian basement

(Proterozoic-Devonian)

Figure 12.3. Interpreted segment of composite reflection seismic line R1 from National Petroleum Reserve-Alaska, approximately 70 km north-northeast of Red Dog, showing a Devonian-Missippian normal fault producing an Endicott-age half graben. Normal fault was later reactivated by a thrust fault. 


\section{Lisburne Petroleum System}

\section{By Julie A. Dumoulin, Robert C. Burruss, and Paul G. Lillis}

The Lisburne Group consists mainly of Carboniferous carbonate rocks formed in a variety of shallow- and deepwater settings. It crops out throughout the Brooks Range and is found in subsurface beneath much of the North Slope in northern Alaska (fig. 13.1). Sulfur-rich oils found in a number of North Slope wells from the Barrow Arch east to Mikkelsen Bay have been interpreted as derived from a Lisburne source, although recent studies suggest that only oils in the Mikkelsen Bay area, and perhaps at Prudhoe Bay, are truly Lisburnesourced (Lillis and others, 2006). Recent field and geochemical data provide information on generation and migration of hydrocarbons within the Lisburne petroleum system (Dumoulin and others, 2005).

Potential hydrocarbon source rocks within the Lisburne in the western and central Brooks Range are deep-water black shales interbedded with radiolarites, carbonate turbidites, and local phosphorites (Kuna Formation and related units). These units are more than $200 \mathrm{~m}$ thick in the Red Dog area (western
Brooks Range) and at least $30 \mathrm{~m}$ thick at Skimo Creek (central Brooks Range; fig. 1.1); shales with total organic carbon (TOC) values greater than 2 percent (locally as high as 20 percent) make up more than two-thirds of these units. Coarse crystalline dolostones in shallow-water facies of the Lisburne that contain vuggy and intercrystalline pores and fractures filled with solid hydrocarbons are found locally throughout the western and central Brooks Range (fig. 13.2). Although much of the Lisburne outcrop reached temperatures too high for oil generation, some sections in the Howard Pass and Chandler Lake quadrangles are still within the oil window (fig. 13.3). Geochemical parameters in rocks with low thermal maturity indicate a good match between organic-rich shales of the Lisburne, hydrocarbon residues in porous dolostones of the Lisburne, and proposed "Lisburne oils" in North Slope wells. In addition to the evidence for generation of liquid hydrocarbons, fluid inclusion observations on cements and organic petrography of solid hydrocarbons in fractures in the Lisburne demonstrate that deeply buried, organic-rich units generated natural gas in the western Brooks Range (Red Dog area), central Brooks Range (Lisburne no. 1 well), and central North Slope (Inigok no.1 well). Structural studies suggest that Lisburne hydrocarbons were generated during the Early Cretaceous as a result of thrust sheet stacking during the Brookian orogeny. 


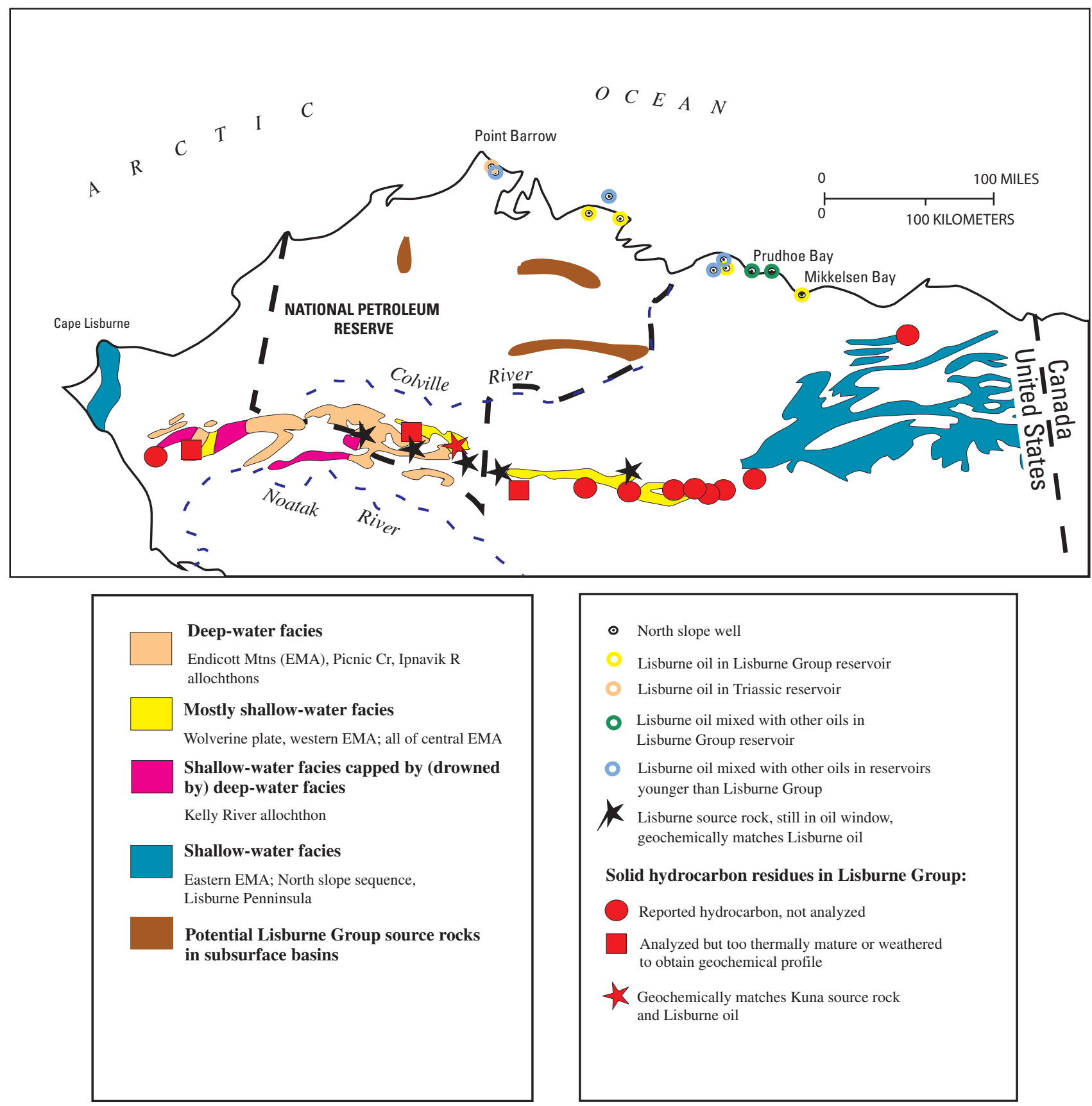

Figure 13.1. Location map of northern Alaska showing distribution of deep- and shallow-water facies of the Lisburne Group, location of North Slope wells, and location of samples used for geochemical analysis. [EMA, Endicott Mountains allochthon] 

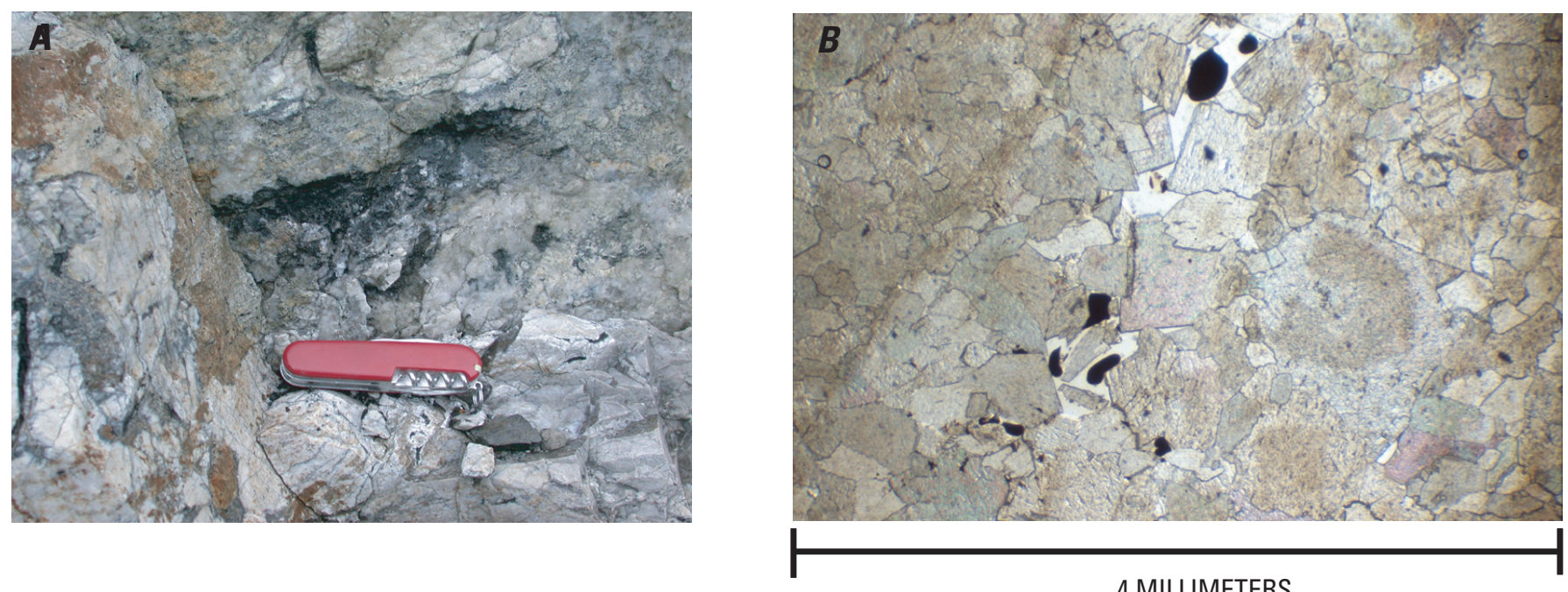

4 MILLIMETERS

Figure 13.2. Photomicrographs of dead oil that show evidence for petroleum migration. $A$, Dead oil in vug lined with quartz and dolomite, Kogruk Formation, Lisburne Group Outcrop near Red Dog mine. Pocket knife is shown for scale. B, Dead oil in Lisburne Group dolostone, Ivotuk Hills locality. Dead oil was extracted and correlated to Lisburne type oil in North Slope reservoirs. 

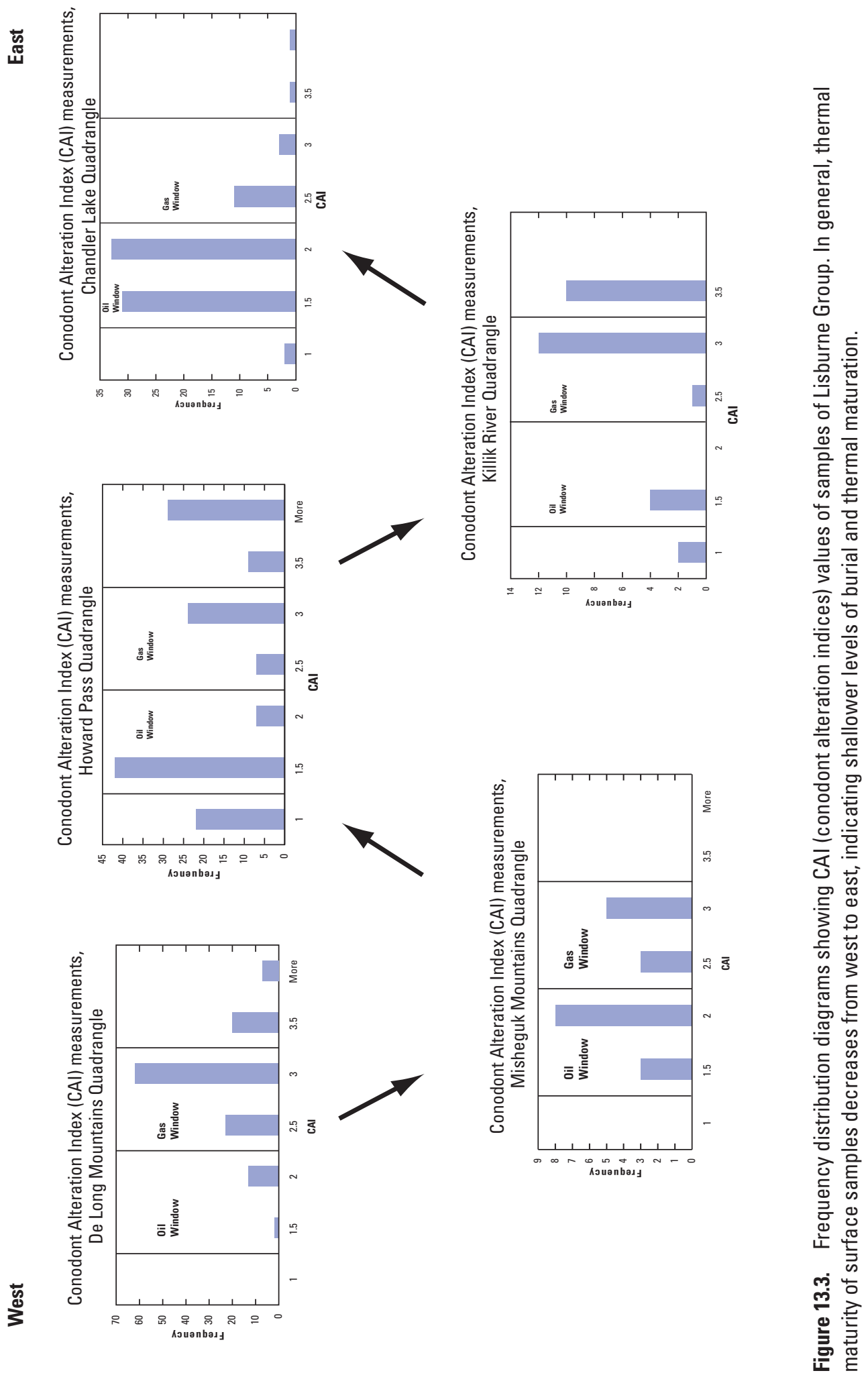

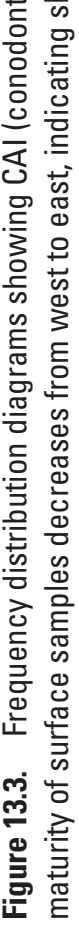




\section{References}

Ayuso, R.A., Kelley, K.D., Leach, D.L., Young, L.E., Slack, J.F., Wandless, G., Lyon, A.M., and Dillingham, J.L., 2004, Origin of the Red Dog Zn-Pb-Ag deposits, Brooks Range, Alaska: Evidence from regional $\mathrm{Pb}$ and $\mathrm{Sr}$ isotope sources: Economic Geology, v. 99, p. 1,533-1,554.

Bird, K.J., 2001, Framework geology, petroleum systems, and play concepts of the National Petroleum ReserveAlaska, in Houseknecht, D.W. ed., 2001, NPRA Core Workshop-Petroleum plays and systems in the National Petroleum Reserve-Alaska: SEPM Core Workshop no. 21, p. 5-17.

Cook, A.C., and Sherwood, N.R., 1991, Classification of oil shales, coals and other organic-rich rocks: Organic Geochemistry, v. 17, p. 211-222.

Coveney, R.M., Jr., and Martin, S.P., 1983, Molybdenum and other heavy metals of the Mecca Quarry and Logan Quarry shales: Economic Geology, v. 78, p. 132-149.

Coveney, R.M., Jr., Murowchick, J.B., and Grauch, R.I., 1992, Early diagenetic or sedimentary origins of fossiliferous Ni-Mo-Au-Pt deposits in Lower Cambrian black shales in China: Journal of Geochemical Exploration, v. 46, no. 2, p. 230-231.

Curtis, S.M., Ellersieck, I., Mayfield, C.F., and Tailleur, I.L., 1984, Reconnaissance geologic map of southwestern Misheguk Mountain quadrangle, Alaska:

U.S. Geological Survey Miscellaneous Investigations Series Map I-1502, scale 1:63,360.

Curtis, S.M., Ellersieck, I., Mayfield, C.F., and Tailleur, I.L., 1990, Reconnaissance geologic map of the De Long Mountains A1 and B1 quadrangles and part of the C2 quadrangle, Alaska: U.S. Geological Survey Miscellaneous Investigations Series Map I-1930, scale 1:63,360.

Desborough, G.A., Poole, F.G., Hose, R.K., and Radtke, A.S., 1979, Metals in Devonian kerogenous marine strata at Gibellini and Bisoni properties in southern Fish Creek Range Eureka County, Nevada: U.S. Geological Survey Open File Report 79-530, 31 p.
DeVera, J., McClay, K.R., and King, A.R., 2004, Structure of the Red Dog district, western Brooks Range, Alaska: Economic Geology, v. 99, p. 1,415-1,434.

Dover, J.H., Tailleur, I.L., and Dumoulin, J.A., comps., 2004, Geologic and fossil locality maps of the west-central part of the Howard Pass quadrangle and part of the adjacent Misheguk Mountain quadrangle, western Brooks Range, Alaska: U.S. Geological Survey Miscellaneous Field Studies Map MF-2413, 2 sheets with 25 p. of explanatory text, scale 1:100,000.

Dumoulin, J.A., Burruss, R.C., Lillis, P.G., and Parris, T.M., 2005, New field and geochemical evidence on the nature and extent of the Lisburne petroleum system, northern Alaska: Geological Society of America, v. 37, no. 4, p. 93.

Dumoulin, J.A., Harris, A.G., Blome, C.D., and Young, L.E, 2004, Depositional settings, correlation, and age of Carboniferous rocks in the western Brooks Range: Economic Geology, v. 99, p. 1,355-1,384.

Dumoulin, J.A., Whalen, M.T., Harris, A.G., and Slack, J.F., 2006, Paleogeographic and metallogenic implications of phosphatic rocks in the Lisburne Group (Permian-Carboniferous), northern Alaska: Geological Society of America Abstracts with Programs, v. 38, p. 85.

Duttweiler, K.A., 1987, Use of factor analyses in locating base-metal mineralization in the Killik River quadrangle, in Hamilton, T.D., and Galloway, J.P., eds., Geologic studies in Alaska by the U.S. Geological Survey during 1986: U.S. Geological Survey Circular 998, p. 27-30.

Ellersieck, I., Curtis, S.M., Mayfield, C.F., and Tailleur, I.L., 1990, Reconnaissance geologic map of the De Long Mountains A2 and B2 quadrangles and part of the C2 quadrangle, Alaska: U.S. Geological Survey Miscellaneous Investigations Series Map I-1931, scale 1:63,360.

Ellersieck, I., Jansons, U., Mayfield, C.F., and Tailleur, I.L., 1982, The Story Creek and Whoopee Creek lead-zinc-silver occurrences, western Brooks Range, Alaska, in Coonrad, W.L., ed., U.S. Geological Survey in Alaska-Accomplishments during 1980: U.S. Geological Survey Circular 844, p. 35-38.

Gradstein, F., and Ogg, J., 2004, Geologic time scale 2004-Why, how, and where next!: Lethaia, v. 37, no. 2., p. 175-181. 
Graham, G.E., Kelley, K.D., Slack, J.F., and Koenig, A.E., in press, Trace elements in $\mathrm{Zn}-\mathrm{Pb}-\mathrm{Ag}$ deposits and related stream sediments, Brooks Range, Alaska, with implications for $\mathrm{Tl}$ as a pathfinder element: Geochemistry: Exploration, Environment, Analyses, submitted.

Hulbert, L.J., Carne, R.C., Gregoire, D.C., and Dogan, P., 1992, Sedimentary nickel, zinc, and platinum-group-element mineralization in Devonian black shales at the Nick Property, Yukon, Canada: A new deposit type: Exploration and Mining Geology, v. 1, p. 39-62.

Jansons, U., 1982, Lead occurrences in and near the National Petroleum Reserve in Alaska: U.S. Bureau of Mines Report MLA 121-82, 85 p.

Johnson, C.A., Kelley, K.D., and Leach, D.L., 2004, Sulfur and oxygen isotopes in barite from the western Brooks Range, Alaska, and implications for the origin of the Red Dog massive sulfide deposits: Economic Geology, v. 99, p. 1,435-1,448.

Kelley, J.S., and Brosgé, W.P., 1995, Geologic framework of a transect of the central Brooks Range; regional relations and an alternative to the Endicott Mountains allochthon: American Association of Petroleum Geologists Bulletin, v. 79, no. 8 , p. $1,087-1,116$.

Kelley, K.D., Dumoulin, J.A., and Jennings, S., 2004, The Anarraaq $\mathrm{Zn}-\mathrm{Pb}-\mathrm{Ag}$ and barite deposit, northern Alaska: Evidence for replacement of carbonate by barite and sulfides: Economic Geology, v. 99, p. 1,577-1,591.

Kelley, K.D., and Jennings, S., 2004, A special issue devoted to barite and $\mathrm{Zn}-\mathrm{Pb}-\mathrm{Ag}$ deposits in the Red Dog district, western Brooks Range, Alaska: Economic Geology, v. 99, p. 1,267-1,280.

Kelley, K.D., and Kelley, D.L., 2003, Metal dispersion and mobility in soils from the Lik $\mathrm{Zn}-\mathrm{Pb}$-Ag sulfide deposit, NW Alaska: Environmental and exploration implications: Geochemistry: Exploration, Environment, Analysis, v. 3, p. 179-195.

Kelley, K.D., Leach, D.L., and Johnson, C.A., 2000, Sulfur-, oxygen-, and carbon-isotope studies of $\mathrm{Ag}-\mathrm{Pb}-\mathrm{Zn}$ vein breccia occurrences, sulfide bearing concretions, and barite deposits in the north-central Brooks Range, with comparisons to shale-hosted massive sulfide deposits, in Kelley, K.D., and Gough, L.P., eds., Geologic studies in Alaska by the U.S. Geological Survey, 1998: U.S. Geological Survey Professional Paper 1615, p. 189-201.
Kelley, K.D., Leach, D.L., Johnson, C.A., Clark, J.L., Fayek, M., Slack, J.F., Anderson, V.M., Ayuso, R.A., and Ridley, W.I., 2004, Textural, compositional, and sulfur isotope variations of sulfide minerals in the Red Dog $\mathrm{Zn}-\mathrm{Pb}-\mathrm{Ag}$ deposits, Brooks Range, Alaska, USA: Implications for ore formation: Economic Geology, v. 99, p. 1,509-1,532.

Kelley, K.D., Taylor, C.D., and Cieutat, B.A., 1997, Silverlead-zinc mineral occurrences in the Howard Pass quadrangle, Brooks Range, Alaska, in Dumoulin, J.A., and Gray, J.E., eds., Geologic studies in Alaska by the U.S. Geological Survey, 1995: U.S. Geological Survey Professional Paper 1574, p. 101-110.

King, A.R., Leach, D.L., Kelley, K.D., Clark, J.L., Young, L.E., Slack, J.F., De Vera, J., and Ayuso, R.A., 2002, A summary of ongoing research in the Red Dog district and possible applications to exploration, in Large, R.R., ed., Stratiform $\mathrm{Zn}-\mathrm{Pb}-\mathrm{Ag}$ deposits and geological environments, with emphasis on the Australian and North American Giants: Society of Economic Geologists/Prospectors and Developers Association of Canada (SEG/PDAC) Workshop, Toronto, March 2002, 6 p.

Kurtak, J.M., Hicks, R.W., Werdon, M.B., Meyer, M.P., and Mull, C.G., 1995, Mineral investigations in the Colville Mining District and southern National Petroleum Reserve in Alaska: U.S. Bureau of Mines Open-File Report 8-95, 217 p.

Large, R.R., Bull, S.W., Selley, D., Yang, J., Cooke, D., Garven, G., and McGoldrick, P., 2002, Northern Australian Proterozoic sediment-hosted $\mathrm{Zn}-\mathrm{Pb}$-Ag deposits: A summary, in Cooke, D.R., and Pongratz, J., eds., Giant ore deposits: Characteristics, genesis and exploration: Centre for Ore Deposit Research Special Publication 4, p. 159-160.

Leach, D.L., Marsh, E., Emsbo, P., Rombach, C., Kelley, K.D., Reynolds, J., and Anthony, M., 2004, Nature of the hydrothermal fluids at the shale-hosted Red Dog zinc-lead-silver deposits, Brooks Range, Alaska: Economic Geology, v. 99, p. 1,449-1,480.

Leach, D.L., Sangster, D.F., Kelley, K.D., Large, R.R., Garven, G., Allen, C.R., Gutzmer, J., and Walters, S., 2005, Sediment-hosted lead-zinc deposits: A global perspective: Economic Geology $100^{\text {th }}$ Anniversary Volume, p. 561-607.

Lillis, P.G., Peters, K.E., and Magoon, L.B., 2006, Oil types of the Alaskan North Slope-A progress report [abs.]: Geological Society of America Abstracts with Programs, v. 38, p. 86 . 
Lillis, P.G., and Stanley, R.G., 2005, Evaluation of petroleum in source rocks from Yukon Flats, east-central Alaska: Geological Society of America Abstracts with Programs, v. 37 , no. 4, p. 93.

Mayfield, C.F., Tailleur, I.L., and Ellersieck, I., 1988, Stratigraphy, structure, and palinspastic synthesis of the western Brooks Range, northwestern Alaska, in Gryc, George, ed., Geology and exploration of the National Petroleum Reserve in Alaska, 1974 to 1982: U.S. Geological Survey Professional Paper 1399, p. 143-186.

Meyer, M.P., and Kurtak, J.M., 1992, Results of the 1991 U.S. Bureau of Mines Colville Mining District study: U.S. Bureau of Mines Open-File Report 75-92, 101 p.

Miller , E.L., and Hudson, T., 1991, Mid-Cretaceous extensional fragmentation of Jurassic-Early Cretaceous compression orogen, Alaska: Tectonics, v. 10, p. 781-796.

Moore, D.W., Young, L.E., Modene, J.S., and Plahuta, J.T., 1986, Geologic setting and genesis of the Red Dog zinclead-silver deposit, western Brooks Range, Alaska: Economic Geology, v. 81, p. 1,696-1,727.

Moore, T.E., and Potter, C.J., in press, Preliminary retrodeformable regional cross section, Kugururok River to Tupikchak Creek, western Brooks Range: U.S. Geological Survey Professional Paper.

Moore, T.E., Potter, C.J., O’Sullivan, P.B., Shelton, K.L., and Underwood, M.B., 2004, Two stages of deformation and fluid migration in the west-central Brooks Range fold-andthrust belt, northern Alaska, in Swennen, R., Roure, F., and Granath, J., eds., Deformation, fluid flow and reservoir appraisal in foreland fold-and-thrust belts: American Association Petroleum Geologists Hedberg Series, no. 1, p. 157-186.

Moore, T.E., Wallace, W.K., Bird, K.J., Karl, S.M., Mull, C.G., and Dillon, J.T., 1994, Geology of northern Alaska, in Plafker, G., and Berg, H.C., eds., The geology of Alaska (v. G-1). The geology of North America: Boulder, Colo., Geological Society of America, p. 49-140.

Morelli, R.M., Creaser, R.A., Selby, D., Kelley, K.D., Leach, D.L., and King, A.R., 2004, Re-Os sulfide geochronology of the Red Dog sedimentary-hosted Zn-Pb-Ag deposits, Alaska: Economic Geology, v. 99, p. 1,569-1,576.

Mull, C.G., 1982, The tectonic evolution and structural style of the Brooks Range, Alaska-An illustrated summary, in Powers, R.B., ed., Geological studies of the Cordilleran thrust belt: Rocky Mountain Association of Geologists, v. 1, p. $1-45$.
Oldow, J.S., Seidensticker, C.M., Phelps, J.C., Julian, F.E., Gottschalk, R.R., Boler, K.W., Handschy, J.W., and Avé Lallemant, H.G., 1987, Balanced cross sections through the central Brooks Range and North Slope, Arctic Alaska: American Association of Petroleum Geologists publication, 19 p., 8 plates, scale 1:200,000.

Ripley, E.M., Shaffer, N.R., and Gilstrap, M.S., 1990, Distribution and geochemical characteristics of metal enrichment in the New Albany Shale (Devonian-Mississippian), Indiana: Economic Geology, v. 85, p. 1,790-1,807.

Schardt, C., Garven, G., Kelley, K.D., and Leach, D.L., in press, Understanding metal transport, fluid mixing, and sulfide mineralization in mudstones at Red Dog: Insights from reactive flow modeling: Geofluids.

Slack, J.F., Dumoulin, J.A., Schmidt, J.M., Young, L.E., and Rombach, C.S., 2004, Paleozoic sedimentary rocks in the Red Dog Zn-Pb-Ag district and vicinity, western Brooks Range, Alaska: Provenance, deposition, and metallogenic significance: Economic Geology, v. 99, p. 1,385-1,414.

Slack, J.F., Kelley, K.D., Anderson, V.M., Clark, J.L., and Ayuso, R.A., 2004, Multistage hydrothermal silicification and Fe-Tl-As-Sb-Ge-REE enrichment in the Red Dog Zn$\mathrm{Pb}-\mathrm{Ag}$ district, northern Alaska: Geochemistry, origin, and exploration applications: Economic Geology, v. 99, p. 1,481-1,508.

Smith, P.S., and Mertie, J.B., Jr., 1930, Geology and mineral resources of northwestern Alaska: U.S. Geological Survey Bulletin 815 .

Stacey, J.S., and Kramers, J.D., 1975, Approximation of terrestrial $\mathrm{Pb}$ isotope evolution by a two-stage model: Earth and Planetary Sciences Letters, v. 26, p. 207-221.

Tailleur, I.L., 1970, Lead-, zinc-, and barite-bearing samples from the western Brooks Range, Alaska: U.S. Geological Survey Open-File Report 70-319, 16 p.

Tourtelot, H.A., and Tailleur, I.L., 1966, Oil yield chemical composition of shale in northern Alaska, U.S. Geological Survey Open File Report 66-131, 17p.

Veizer, J., Davin, A., Azmy, K., Bruckschen, P., Buhl, D., Bruhn, F., Carden, G.A.F., Diener, A., Ebneth, S., Godderis, Y., Jasper, T., Korte, C., Pawellek, F., Podlaha, P.G., and Strauss, H., $1999,{ }^{87} \mathrm{Sr} /{ }^{86} \mathrm{Sr}, \delta^{13} \mathrm{C}$, and $\delta^{18} \mathrm{O}$ evolution of Phanerozoic seawater: Chemical Geology, v. 161, p. 59-88. 
Werdon, M.B., 1999, Geologic setting of Mississippian veinbreccias at the Kady $\mathrm{Zn}-\mathrm{Pb}-\mathrm{Cu}-\mathrm{Ag}$ occurrence: Plumbing system for a failed SEDEX deposit?, in Kelley, K.D., ed., Geologic studies in Alaska by the U.S. Geological Survey, 1997: U.S. Geological Survey Professional Paper 1614, p. 5-55.

Werdon, M.B., Layer, P.W., and Newberry, R.J., 2004, ${ }^{40} \mathrm{Ar} /{ }^{39} \mathrm{Ar}$ dating of $\mathrm{Zn}-\mathrm{Pb}-\mathrm{Ag}$ mineralization in the northern Brooks Range, Alaska: Economic Geology, v. 99, p. $1,323-1,344$.

Young, L.E., 1989, Geology and genesis of the Red Dog deposit, western Brooks Range, Alaska: Canadian Institute of Mining and Metallurgy Bulletin, v. 82, no. 929, p. 57-67.

Young, L.E.,1995, Empirical applications of common lead-isotope ratios to exploration: Society of Economic Geologists Newsletter no. 22, p. 7-12.

Young, L.E., 2004, A geologic framework for mineralization in the western Brooks Range, Alaska: Economic Geology, v. 99 , p. 1,281-1,306. 


\section{Glossary of terms}

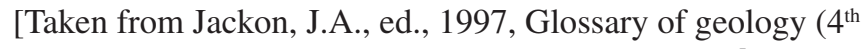
ed.): Alexandria, Va., American Geological Institute]

Element symbol definitions

$\mathrm{Ag}$ - silver

As - arsenic

$\mathrm{Au}-$ gold

$\mathrm{Ba}-$ barium

$\mathrm{Ce}-$ cerium

$\mathrm{Cr}-$ chromium

$\mathrm{Cu}$ - copper

$\mathrm{Eu}-$ Europium

$\mathrm{F}$ - fluorine

$\mathrm{Ge}$ - germanium

$\mathrm{Hg}$ - mercury

Mo - molybdenum

$\mathrm{Ni}-$ nickel

$\mathrm{O}$ - oxygen

$\mathrm{P}$ - phosphorus

PGE - platinum group elements

$\mathrm{Pb}-$ lead

REE - rare earth elements

$\mathrm{S}$ - sulfur

$\mathrm{Sb}$ - antimony

$\mathrm{Se}-$ selenium

$\mathrm{Sr}-$ strontium

$\mathrm{Tl}$ - thallium

$\mathrm{U}$ - uranium

$\mathrm{V}$ - vanadium

$\mathrm{Zn}-$ zinc

\section{A}

allochthon A mass of rock that has been moved from its place of origin by tectonic processes.

anoxic Relating to a marked lack or difficiency of oxygen; for example, oceanic anoxia refers to an absence of oxygen in seawater $(<0.1 \mathrm{ml} / \mathrm{l})$.

autochthon A mass of rock that remains at its site of origin, where it is rooted to its basement.

\section{B}

barite Barium sulfate mineral $\left(\mathrm{BaSO}_{4}\right)$.

\section{C}

calcareous A substance that contains calcium carbonate $\left(\mathrm{CaCO}_{3}\right)$.

carbonate A mineral compound; calcite is an example

$\left(\mathrm{CaCO}_{3}\right)$. chalcopyrite A bright brass yellow mineral composed of copper, iron, and sulfur $\left(\mathrm{CuFeS}_{2}\right)$.

chert A hard, dense, microcrystalline sedimentary rock, consisting dominantly of quartz.

conodont Microfossil, commonly toothlike in form made up of carbonate and apatite.

contraction Tectonic processes resulting in shortening.

D

diagenetic Chemical, physical, and biologic changes undergone by a sediment after its initial deposition and during and after its lithification.

dolomite A rhombohedral mineral $\left(\mathrm{CaMg}\left(\mathrm{CO}_{3}\right)_{2}\right.$ that is white, colorless, or tinged yellow, brown, pink, or gray.

dolostone A rock made up of the mineral dolomite, a mineral with the composition of $\mathrm{CaMg}\left(\mathrm{CO}_{3}\right)_{2}$.

dysoxic Below normal concentration of oxygen in seawater (0.1 to $1.0 \mathrm{ml} / \mathrm{l})$.

E

extension Tectonic process resulting in elongation (pullapart).

$\mathbf{F}$

facies The aspect, appearance, and characteristics of a rock unit, usually reflecting the conditions of its origin; a mappable, areally restricted part of a lithostratigraphic body, differing in lithology or fossil content from other beds deposited at the same time.

fluid inclusions In a mineral, a tiny cavity (micron sized in diameter), containing liquid and (or) gas, formed by the entrapment in crystal irregularities of fluid, commonly that from which the rock crystallized.

G

galena Lead sulfide $(\mathrm{PbS})$ mineral.

gangue Valueless rock or mineral aggregates in an ore; that part of an ore that is not economically desirable but cannot be avoided in mining.

H

hydrothermal Of or pertaining to hot water, to the action of hot water, or to the products of this action, such as a mineral deposit precipitated from a hot aqueous solution. 
K

kerogenous Said of oil shale or other sedimentary rock containing complex fossilized organic material that is insoluble in common organic solvents and yields petroleum on distillation.

klippe An isolated rock unit that is an erosional remnant or outlier of a sheetlike allochthonous rock unit.

\section{L}

lithology The description of rocks in hand sample or outcrop on the basis of such characteristics as color, mineralogic composition, and grain size.

\section{M}

marcasite Iron sulfide $\left(\mathrm{FeS}_{2}\right)$ mineral. It may be differentiated from pyrite based on lower specific gravity, less chemical stability, and usually a paler color.

metalliferous Metal-bearing.

mica A group of minerals with low hardness, readily splitting into thin plates.

mudstone An indurated mud having the texture and composition of shale but lacking its fine lamination; fine-grained sedimentary rock.

\section{$\mathbf{N}$}

nodule A small irregularly rounded mass of a mineral or mineral aggregate, usually exhibiting a contrasting composition from the enclosing sediment or rock in which it is embedded.

\section{0}

oil shale A general term applied to a fine-grained sedimentary rock containing enough organic material (called kerogen) to yield oil and combustible gas upon distillation.

orogeny The process of formation of mountains.

\section{$\mathbf{P}$}

paleogeography The study and description of the physical geography of the geologic past.

passive margin A continental boundary formed by rifting and continental rupture.

per mil Parts per thousand.

phosphate A mineral compound containing $\mathrm{PO}_{4}^{-3}$ groups.

phosphorite A sedimentary rock with a high enough content of phosphate minerals to be of economic interest.

pyrite Iron sulfide $\left(\mathrm{FeS}_{2}\right)$ mineral. It has a higher specific gravity, more chemical stability, and a brighter metallic luster compared to marcasite. $\mathbf{0}$

quartz Crystalline silica, an important rock-forming mineral $\left(\mathrm{SiO}_{2}\right)$.

$\mathbf{R}$

radiogenic A product of a radioactive process (heat, lead).

radiolarian Microfossil characterized mainly by a siliceous skeleton and a marine pelagic environment; the silica is often replaced by other minerals.

rudstone A carbonate rock composed of bioclasts or other fragments, over $2 \mathrm{~mm}$ in diameter, closely packed, in physical contact.

\section{S}

sabkha Supratidal environment of sedimentation, formed under arid to semiarid conditions on restricted coastal plains.

salinity Total quantity of dissolved salts in seawater.

sandstone Medium-grained clastic sedimentary rock composed of abundant rounded or angular fragments of sand size set in a fine-grained matrix and united by a cementing material.

shale Fine-grained detrital sedimentary rock, formed by the consolidation of clay, silt, or mud; characterized by finely laminated structure, which imparts a fissility parallel to the bedding.

siliciclastic Clastic noncarbonate rocks which are almost exclusively silicon bearing.

siltstone Indurated silt having the texture and composition of shale but lacking its fine lamination or fissility.

sphalerite Zinc sulfide $(\mathrm{ZnS})$ mineral.

strata plural of stratum which is a tabular or sheetlike body or layer of a sedimentary rock.

stratiform Having the form of a layer; a stratiform ore deposit is one that is strictly coextensive with a given rock unit.

sulfide A mineral compound characterized by the linkage of sulfur with a metal or semimetal. Examples include sphalerite (zinc sulfide), galena (lead sulfide), or pyrite (iron sulfide).

synsedimentary Said of a sedimentary ore deposit in which the ore minerals formed contemporaneously with the enclosing rock.

\section{$\mathbf{T}$}

turbidite A sediment or rock deposited from a turbidity current. 
